\title{
Firm employment growth in China: The role of marketization and regional economic factors
}

\author{
Peng Bin $^{1}$ | Xiaolan Chen ${ }^{2}$ | Andrea Fracasso ${ }^{3}$ (iD | Chiara Tomasi,
}

${ }^{1}$ College of Public Administration, Huazhong Agricultural University, Wuhan, China

${ }^{2}$ School of Economics, Sichuan University, Sichuan, China

${ }^{3}$ Department of Economics and Management, School of International Studies, University of Trento, Trento, Italy

${ }^{4}$ Department of Economics and Management, University of Trento, Trento, Italy

${ }^{5}$ LEM, Scuola Superiore S.Anna, Pisa, Italy

\section{Correspondence}

Andrea Fracasso, Department of Economics and Management, School of International Studies, University of Trento, Via Inama 5, Trento 38122, Italy.

Email: andrea.fracasso@unitn.it

\begin{abstract}
Very heterogeneous patterns of firm employment growth characterize the Chinese provinces, suggesting the existence of a relationship between these and regional factors. This empirical work explores this topic by providing novel evidence of the role played by regional institutional and regional factors in firm employment growth in China during the decade 1998-2007, an important period in the Chinese transition towards a market economy. The results show that controlling for the internal determinants of firm performance, the firms located in provinces converging faster towards a market economy, exhibiting relatively better patterns (in terms of agglomeration, endowment of human capital, innovation and environmental protection) tend to expand their employment relatively more. These findings confirm the existence of a macro-micro-connection as to what firm heterogeneity is concerned, as they reveal a differential growth channel along the regional dimension. In particular, local progress in government-market relationships appears as the most relevant dimension of marketization process. Given the regionally decentralized institutional system in China and considering its process of transformation, these findings inform local authorities concerned with the promotion of regional employment.
\end{abstract}




\section{INTRODUCTION}

Firm growth, a phenomenon at the core of economic dynamics, has been one of most widely studied topics in economic literature. ${ }^{1}$ Through the expansion of firms, the economy generates new employment and business opportunities. Employment dynamics, in turn, is a key concern for policy makers, in particular in those countries experiencing a process of structural change and transition from a planned to a market economy. Hence, understanding the factors that ease (or hamper) firm employment growth has been of utmost relevance not only for entrepreneurs and managers, but also for policy makers and economic researchers.

Beginning with the well-known Gibrat's law in 1931, an extensive academic literature has flourished in the attempt to identify empirically those firm-specific attributes and strategies (such as size, age, ownership type, innovation and financial conditions) that are associated with firm growth. While much attention has been paid to the micro-level characteristics driving firm performance, less is still known about the role played by regional factors, notwithstanding the consensus that context-specific conditions matter for firm dynamics, especially in a process of structural change and transition towards a market economy. Few are indeed the studies examining the potential relationship between the regional environment in which the firms operate and their employment dynamics. This is surprising as it seems important to understand to what extent the observed heterogeneity in firms' growth rates within a country is associated with the geographical dispersion of the place-dependent determinants of firm growth or rather with the uneven distribution of firm-level characteristics across regions; the underestimation of regional variation in institutions and local environment as driving force of employment dynamics is particularly serious in transitional economies. ${ }^{2}$

This paper seeks to contribute to the debate on the sources of firm employment growth by addressing whether regional institutional and economic factors stand out as significant determinants of firm employment growth, in addition to traditional firm-level characteristics. The analysis tests the impact of regional features on firm employment growth using a large database of Chinese manufacturing firms in the decade 1998-2007. China in this historical period represents an interesting environment to address this issue given the unique combination of four circumstances: the extraordinary fast development of the economy; the remarkable regional heterogeneity in terms of economic and institutional conditions; the transition from a planned to a market economy; and the highly differentiated rates of growth of firms across provincial regions within the same industry (and across industries within the same province). Indeed, since 1978, China has undergone a process of gradual and incremental reforms from a centralized economy to a 'socialist market economy'. ${ }^{3}$ While the economic growth in this country has been exceptional during the reform era, it is by no means even across the country's 31 provinces, centrally administered municipalities and autonomous regions. Table A1 in online Appendix provides some prima facie evidence of the large variation in firm employment growth across the Chinese provinces by reporting the average growth rates of firm employment in 2007 for the four main industries across the Chinese provinces. It shows that within each industry, the extent of regional variation in employment growth is very large, and within each province, industries differ remarkably in terms of average firm employment growth. Based on this evidence and on the fact that the literature documented a very large spatial variation of economic institutions and other local economic factors across regions in China (Du, Lu, \& Tao, 2012; He, Wei, \& Xie, 2008; Lu, Png, \& Tao, 2013), we investigate whether regional variation in economic factors and institutional arrangements has had an impact on individual firms' employment growth.

The main question this paper addresses, thus, is to what extent regional economic and institutional features matter to explain employment growth at the firm level in China. With respect to previous studies, the empirical analysis produced in this work contributes to a better understanding the institutional 
sources of firm heterogeneity by adopting a micro-level perspective. In so doing, it complements those works that explored the determinants of the differentials in regional economic growth (see Zhang \& Zou, 2012, for a survey) using highly aggregated data. More precisely, building on very recent works showing the impact that local economic institutions have on firms' decisions and performances in countries different from China (Ganau \& Rodriguez-Pose, 2019; Ketterer \& Rodriguez-Pose, 2018; Lasagni, Nifo, \& Vecchione, 2015; Meyer \& Nguyen, 2005; Nguyen, Le, \& Bryant, 2013), this paper focuses on the role played by the regional level of market/regulatory/legal development, that is, the local degree of marketization, in affecting the individual firms' employment decisions. Economic liberalization is indeed expected to create an environment favouring entrepreneurial activities and firm employment growth. The degree of marketization, that is often considered as a proxy for the quality of the institutional environment in a transition country, has been traditionally measured in China by means of an ad hoc composite index, indicating how each Chinese province scores with respect to the others in terms of its progress towards the realization of a fully fledged market economy. The marketization index, created and updated by Fan, Xiaolu, and Zhu (2007), Fan, Xiaolu, and Guarong (2011), Fan et al. (2017) and published by the National Economic Research Institute (NERI), is based on official statistics as well as on information derived from entrepreneurs and households surveys and it covers progress in five important aspects: the relationship between government and the market, the growth of the private sector, the development of the product/commodity markets, the evolution of factors' markets and the transformation towards a market-friendly legal environment. The NERI variable captures the evolution of regional differences across Chinese provinces, thus making a comparison over time and across areas possible. In addition to marketization, our analysis takes into account also other regional economic factors such as the extent of agglomeration economies and dis-economies, the level of human capital, the intensity of the efforts to promote innovation and environmental protection across provinces. For all of these, the literature has already shown a high relevance in affecting the spatial variation of aggregated economic development and some evidence is available also on their impact on firm productivity growth; little is instead known on how they relate to firm employment growth. All the variables are drawn from official Chinese statistical yearbooks (various years 1999-2008) published by the National Bureau of Statistics.

Anticipating the main results of the analysis, heterogeneous performances in firm employment growth appear not only to be due to differences in the characteristics intrinsic to the firms, but also amenable to the uneven pace of institutional reforms and other economic factors across provinces. Firm employment grows faster for companies located in Chinese provinces with higher level of marketization, exhibiting higher degree of agglomeration economies, endowed with more advanced educational schemes and more engaged in innovative activities. These findings are robust to a series of alternative specifications, samples and definitions of the variables of interest.

Within the vast literature on firm growth, this article relates to the empirical literature that examines the regional determinants of growth. The idea that regional institutional and economic conditions are fundamental drivers of growth has been extensively considered by the macroeconomic and the regional literature, but few empirical studies have considered firm employment growth. As noted by BravoBiosca, Criscuolo, and Menon (2016), there is no paucity of work showing that local factors may impact on the aggregate local economic performance, but very few studies focus on the impact of framing conditions on firm-level growth heterogeneity. Gabe and Kraybill (2002) assess the effects of economic policy measures (i.e., state development incentives) on the growth of a number of establishments in Ohio while controlling also for local market conditions and industrial agglomeration. Beck, DemirgucKunt, and Vojislav (2005) exploit a firm-level survey database to assess the impact of institutional quality on firm dynamics, showing the differentiated effect of financial, legal and corruption problems on firm growth rates across 54 countries. Audretsch and Dohse (2007) provide evidence that there are 
systematic differences in the growth rates of enterprises engaged in the same industry across different geographical areas and that the regions more abundant in knowledge-related resources have firms growing faster. Exploiting the variation across Portuguese regions, Barbosa and Eiriz (2011) find evidence that region-specific characteristics (e.g., industrial diversity, entrepreneurship potential and workforce qualities) impact remarkably on the way individual firms grow. More recently, Ipinnaiye, Lenihan, and Doran (2017) explore the role of regional market conditions, innovation and human capital to account for heterogeneity in firm growth in Ireland, whereas Ipinnaiye, Dineen, and Lenihan (2017) investigate the impact of macroeconomic conditions (such as unemployment, inflation, real effective exchange rate and credit conditions) on small and medium-sized enterprise growth. ${ }^{4}$

Looking more closely to the case of China, numerous empirical works have studied the underlying determinants of the heterogeneous growth across regions in the post-reform era. As far as the impact of the local implementation of market-oriented reforms is concerned, Fan et al. (2011) analyse aggregate data on 30 provincial regions over the period from 1997 to 2007 and show that the contribution of marketization to economic growth was around $1.45 \%$ per year. ${ }^{5}$ Yet, research efforts on firm employment growth at the micro-level are still scant because most firm-level studies focus on the relationship between local institutions and conditions, on the one hand, and entrepreneurial performances, entry, survival and exit, on the other hand. ${ }^{6}$ In a nutshell, these studies show that higher levels of marketization are associated with a more lively entrepreneurship, as well as higher entry and exit rates (Che, Lu, \& Tao, 2017; Cull \& Xu, 2005; Hasan, Kobeissi, Wang, \& Zhou, 2015; He \& Yang, 2016; Lai \& Vonortas, 2019; Liu \& Huang, 2016; Lu \& Tao, 2010; Pan \& Yang, 2019; Qian, 2010; Song \& Winkler, 2014; Zhou, 2011; Zhou \& Hall, 2017). ${ }^{7}$ Zhou (2011) finds that regional deregulation plays a significant role in China's entrepreneurial growth within regions. Che et al. (2017) find evidence that institutional quality (in terms of property rights protection and government corruption) positively impacts on the survival of private manufacturing firms in China for the 1998-2005 period. Lai and Vonortas (2019) show that human capital, knowledge creation and access to finance are the main factors behind local entrepreneurial activity in the period 2008-2015. Liu and Huang (2016) explore the relationship between local financial capital, human capital and social capital and entrepreneurial entry in Chinese urban areas. Lu and Tao (2010) construct various dummy variables referring to China's institutional environment and show that they correlate with entrepreneurship decisions. Hasan et al. (2015) and Zhou and Hall (2017) focus on the effect that the regional banking structures and the marketization index have on the changes in the number of private enterprises and self-employed individuals. Using the annual survey of industrial firms during 1998-2007, He and Yang (2016) show that local policies, such as subsidies and banking loans, reduce the chance of firm failure. Pan and Yang (2019) analyse the geographical agglomeration of start-ups in cities and the impact of financial development on local entrepreneurial activities. He, Yan, and Rigby (2018) find that regional industrial development is path-dependent and that local conditions matter in terms of firms' exit and entry. ${ }^{8}$

To the best of our knowledge, no study has yet looked at the relationship between institutional quality and other local covariates, on the one hand, and firm employment growth, on the other hand, in China. It follows that this paper contributes to the literature by investigating the effect that marketization and other regional economic factors exerted on firm employment growth in China during this period of its transition process. Our analysis reveals that the progressive improvement in the level of marketization fostered economic growth not only through increased industry dynamics, net firm entry and entrepreneurship), as shown by the studies mentioned above, but also by facilitating the expansion of employment in the incumbent firms. Overall, our work suggests that various economic features of the regional environment in which the firms operate are important drivers of their growth.

It is worth noticing at this stage that while the evidence on the impact of regional factors on firm employment growth in China is scarce, there is no paucity of studies addressing the firm-level 
determinants of employment (see Degryse, Lu, \& Ongena, 2016; Dosi \& Yu, 2019; Moschella, Tamagni, \& Yu, 2019; Yu, Dosi, Grazzi, \& Lei, 2017, among others). Our empirical investigation takes stock of these and other contributions on firm-level covariates and complements these studies in that it analyses the regional economic and institutional determinants of the observed heterogeneity in firm employment growth across the Chinese provinces.

The remainder of the paper proceeds as follows. Section 2 presents the theoretical framework and links firm employment growth to regional institutional and economic characteristics. Section 3 presents the economic variables and the data, thereby introducing a few descriptive statistics. The empirical specification and the estimation results will be illustrated in Section 4. A battery of robustness checks and extensions will be presented in Section 4.3. Section 5 will conclude by offering some closing remarks.

\section{I REGIONAL DETERMINANTS OF FIRM EMPLOYMENT GROWTH}

The idea that regional features may play a decisive role in conditioning and steering the development process, as well as the economic success or decline of countries and regions, has been extensively considered in the economic literature. Numerous studies investigate spatial variations in several factors that may cause differentials in economic growth, ranging from government policies, institutional quality, openness to the world market, market integration, public infrastructures, education attainment, technologies, environmental policies and the like.

A prominent line of research looks at the impact of market-oriented reforms on economic growth (Falcetti, Raiser, \& Sanfey, 2002; Roland, 2000). ${ }^{9}$ Mainly thanks to works focusing on data at the national and regional levels of aggregation, this literature generally indicates a positive relationship between "marketization" and economic outcomes in various countries (Babecky \& Campos, 2011; de Melo, Denizer, Gelb, \& Tenev, 2001), and also in China (Fan et al., 2011; Fan, Guarong, \& Xiaolu, 2018). Because the process of structural change and transition towards a market economy is generally coupled with institutional changes, marketization is closely associated with institutional development: without reliable institutions, whether formal or informal, markets cannot normally function well and deliver economic growth. The economic literature has widely recognized that the quality of institutions operating in the geographical areas where the firms are located crucially contributes to forming the set of incentives underlying entrepreneurs' and managers' behavior and individual choices (see, among others, Acemoglu \& Robinson, 2010; Aron, 2000; Dawson, 1998; Easterly \& Levine, 2003; Gwartney, Holcombe, \& Lawson, 2004; Kim \& Law, 2012; North, 1991; Smallbone \& Welter, 2012). A well-functioning legal system that secures property rights, for instance, is necessary for firms' investment and, eventually, for their long-term economic growth. Besides the legal protection of property rights, in a developed market economy uncertainty is lower and the rules of the game are clearer, thereby making incentives more transparent. By decreasing transaction and production costs (e.g., the prices of various factors and commodities), good economic institutions make certain exchanges more profitable and increase the number of potential exchanges. Good institutions also encourage firms to use better technology, invest in knowledge creation, train workers and undertake the similar strategies, all with a positive impact on competitiveness and economic performance.

The role of regional variation in the quality of institutions has been acknowledged to be particularly important in China, given the tremendous institutional changes occurred after its opening up, together with the fact that the country has traditionally been a regionally decentralized system (Xu, 2011). For this reason, as anticipated in the Introduction, some recent studies have drawn the attention on 
the consequences of the development of economic institutions (including property rights protection and contract enforcement) at the local level, and the degree of marketization has been found to be particularly important both for macroeconomic growth and for entrepreneurship and firm dynamics. However, little is known about its implications on individual firm employment growth. Intuitively, one could expect that where market forces work more freely, the incentives are better aligned and firms with greater opportunities grow more. If this intuition is correct, the quality of economic institutions could be expected to have a positive influence on the overall economic growth not only through its positive impact on entrepreneurship and net firm entry (as already documented), but also via its effects on the expansion of individual incumbent firms. Luckily, testing this hypothesis is made possible by the fact that the China's gradual transition towards a market economy and its regionally decentralized institutional system ensure enough regional and temporal variation in the degree of marketization to assess its impact on individual firms' employment growth. Notably, Fan et al. (2017) have shown that the standard deviation of provincial scores in terms of marketization have widened after 1997, even though all the Chinese provinces made positive progress over time.

Together with institutional factors, other regional economic variables can possibly affect various dimensions of firms' economic performance and, specifically, firm employment growth. By taking stock of previous macroeconomic and regional studies, we consider the presence of factors specific to regions but common to industries, factors that are common to industries but not geographically differentiated, and factors varying across both regions and industries. ${ }^{10}$ Accordingly, this work considers agglomeration economies and dis-economies, the stock of human capital, the intensity of local efforts to promote innovation and the strength of environmental protection, besides some time-invariant industry and regional factors. We illustrate in what follows the reasons why these local economic factors are considered as the regional covariates of firm employment growth in the estimations.

As regards agglomeration economies, several theories dating back to Marshall in 1980 suggest that proximity to other economic activities enhances firms' level of productivity (in case of static externalities) and productivity growth (in case of dynamic externalities). Such localized effects mainly refer to knowledge spillovers and labour pooling, but also other mechanisms are at work. Agglomeration effects, for instance, may have to do with the intensity of local competition, the level of industry specialization, the availability of specific infrastructures and the creation of a network of interacting firms. In particular, agglomeration economies are expected to be higher in highly specialized areas (whereby sector-specific scale economies lead to the so-called localization economies, as explained by Duranton \& Puga, 2004; Rosenthal \& Strange, 2004) and in densely populated areas (due to urbanization economies and Jacobian externalities available to all firms in a region independently from the industry, as discussed in Melo, Graham, \& Noland, 2009). Both agglomeration economies may exercise a positive effect on firm employment growth (see Beaudry \& Schiffauerova, 2009, for an overview), at least to the extent that they are not offset by congestion effects and negative externalities (such as pollution, higher average wages and higher land rents). While the implications of agglomeration on growth have been largely studied from the regional perspective using aggregated regional data, relatively few studies addressed localization and urbanization economies by looking at the employment growth of individual firms (Audretsch \& Dohse, 2007; Barbosa \& Eiriz, 2011; Bojas \& Barbosa, 2015; Duschl, Scholl, Brenner, Luxen, \& Raschke, 2015; van Oort, Burger, Knoben, \& Raspe, 2012). ${ }^{11}$

The literature on knowledge spillovers has revealed that the features of local innovation systems' impact on the growth rate of companies and, more generally, on their economic performances (see Beaudry \& Schiffauerova, 2009; Dosi \& Nelson, 2010). In accordance with the theory of entrepreneurship developed by Audretsch (1995), the access to the knowledge generated within a geographical area may indeed affect firms' propensity to create new economic opportunities and to introduce new ideas in the market: this, in turn, makes them grow at a faster rate. Furthermore, knowledge spillovers can 
help firms reduce uncertainty and the cost of innovation, thereby boosting investment and growth. The empirical evidence that the local accumulation of knowledge (measured in terms of R\&D expenditures, patents, innovation counts or questionnaire results) spurs firms' productivity and growth is abundant (Cassia, Colombelli, \& Paleari, 2009; Geenhuizen \& Reyes-Gonzalez, 2007; Gilbert, McDougall, \& Audretsch, 2008). In particular, recent firm-level studies (e.g., Cecere \& Mazzanti, 2017; Horbach \& Janser, 2016; Kunapatarawong \& Martinez-Ros, 2016; Leoncini, Marzucchi, Montresor, Rentocchini, \& Rizzo, 2019) have shown that green innovation is particularly conducive to employment growth by favouring cost-saving and pushing labour-absorbing investment. Accordingly, the size of local green investment projects can be considered as a good proxy of the local sensitiveness to the environment, which in turn captures the incentives to labour-absorbing, green investment. Moreover, as firms' green innovation is often backed by local public incentives, the diffusion of green investment projects may indirectly reflect also features of local institutions and policies. ${ }^{12}$

The local endowment of human capital is likely to be a relevant regional determinant of firm employment growth (Audretsch \& Dohse, 2007). Moretti (2004a) shows the existence of various mechanisms whereby the increase in knowledge and skills in a region can affect the local economic outcomes in ways that exceed the private return to education. Moretti (2004b) provides evidence that firms' productivity growth is larger in cities that experience large increases in the share of college graduates. In the presence of externalities, the aggregate endowment of human capital may boost firm growth because it positively affects entrepreneurial abilities and motivations (Davidsson, 1991; Van Praag \& Cramer, 2001) and, more importantly in our framework looking at the evolution of the size of incumbent firms, because it spurs the performance of the average entrepreneur (Milln, Congregado, Romn, Praag, \& Stel, 2014). Finally, social interactions among educated workers create additional localized learning opportunities that enhance firm growth. Because education attainment varies a lot across regions in China, with huge inequality in college access between rural youth from poor counties and urban youth, plenty of empirical analyses have explored the implication that this inequality has for China's social and economic development. However, as suggested also by Zhu, He, and Luo (2019), more research on the effect of regional disparities in education attainment and human capital needs to be done at the micro-level.

It is worth stressing one last time before proceeding that while there is abundant regional-level evidence about the relevance of all these variables on production and employment growth, this work focuses on a less investigated aspect, that is the average impact of such regional factors on the evolution of the size of the incumbent firms. It is for this reason that we draw on the conclusions of various regional-level studies (both on China's and on other countries' data) to see whether the results hold also in our firm-level set-up. That this is the case, in fact, is not forgone: Beaudry and Schiffauerova (2009), for instance, provide ample evidence that firm-level studies tend to inflate localization externalities, while regional-level analyses have the tendency to inflate Jacobian externalities.

\section{3 | DATA AND METHODS}

This Section presents the data set and the variables used in our empirical model and it provides some descriptive statistics for the main variables of interest.

\section{1 | Firm-level growth data}

The analysis covers microeconomic firm-level data derived from the annual accounting reports filed by Chinese industrial firms for the Chinese Annual Survey of Industrial Production. ${ }^{13}$ All the SOEs 
and the non-SOE firms with annual sales of at least five million Yuan are included in the sample. Although firms with annual sales below such threshold are not included, they account for less than $10 \%$ of the aggregate output (in 2004) and their exclusion has been shown not to bias the empirical analysis.

The initial (unbalanced) data set on all the industrial industries covers more than 2 million firm-year observations, ranging from 165,000 firms in 1998 to almost 337,000 firms in 2007. Table 1 reports the main statistics for some key variables. For the sake of brevity, we refer to Brandt, Biesebroeck, and Zhang $(2012,2014)$ for a detailed description of this data set and for a discussion of data issues that need to be addressed to obtain reliable information, necessary in particular to ensure a correct matching of the reporting firms over time (whereby restructuring processes and privatizations are duly taken into account). Observations with negative values for some relevant variables (i.e., output, capital, intermediate input, labour, value added) are dropped from the sample: after cleaning the data set and retaining only the manufacturing firms, we end up with an unbalanced panel that increases in size from 121,505 firms in 1998 to 291,076 in 2007.

Our main empirical interest lies in the regional determinants of firm employment growth in China. The dependent variable is therefore the firm-level employment growth $\left(\Delta \ln \operatorname{Empl}_{f, t}\right)$ measured as the annual percentage growth rate of the number of employees and calculated by taking the logged difference of the employees hired by firm $f$ from period $t$ and $t-1$. As discussed by Coad and Holzl (2012) and Peric and Vitezic (2016), there exist many measures (ranging from assets to sales) that the applied researcher can choose among to study the evolution of firm size. The most common indicators in the literature are either the number of employees or the value of sales (Delmar, 1997). As sales, revenues and profits mirror well the economic performance of a company, they are the indicators most commonly used by managers and entrepreneurs to assess performance. Employment, instead, is relatively more often associated with socio-economic dimensions that are of interest for policy makers, macroeconomists and regional economists. Given the research question addressed in this work, our attention will fall on employment, and sales will be considered only in an auxiliary estimation for the sake of completeness. The adoption of annual percentage growth rates allows to capture the shortterm determinants of firm growth and to include enterprises present in the sample only for a limited number of years.

TAB LE 1 Original sample

\begin{tabular}{|lcccc|}
\hline Year & \# Firms & Output & Sales & Employment \\
\hline 1998 & 165,118 & 6.77 & 6.54 & 56.4 \\
\hline 1999 & 162,033 & 7.27 & 7.06 & 58.1 \\
\hline 2000 & 162,883 & 8.57 & 8.37 & 53.7 \\
\hline 2001 & 169,028 & 9.40 & 9.18 & 53.0 \\
\hline 2002 & 181,557 & 11.1 & 10.9 & 55.2 \\
\hline 2003 & 196,222 & 14.2 & 13.9 & 57.5 \\
\hline $2004^{\mathrm{a}}$ & 279,090 & & 19.9 & 66.3 \\
\hline 2005 & 271,835 & 25.2 & 24.7 & 69.3 \\
\hline 2006 & 301,961 & 31.7 & 31.1 & 73.5 \\
\hline 2007 & 336,768 & 40.5 & 39.8 & 79.3 \\
\hline
\end{tabular}

Note: Sales and output in trillion RMB. Employment in million workers.

${ }^{a}$ Industrial output is not available for 2004 (see Brandt et al., 2014). 


\section{2 | Province-level independent variables}

The regional drivers of firm employment growth introduced in the empirical specification are the following: level of marketization, level of agglomeration, human capital, innovation, and environmental protection. To this end, we use measures derived either from the manipulation of the series in the original firm-level data set (so as to produce variables for each province-industry pair in each period), or from the official Chinese statistical yearbooks (various years 1999-2008) published by the National Bureau of Statistics. These latter do not vary across industries and take different values exclusively across provinces and over time. ${ }^{14}$

Importantly, to capture the differences across provinces in the quality of economic institutions and policies, and more precisely in the level of market/regulatory/legal institutions that might affect firms' employment growth, we employ the index of marketization (Marketization Index $x_{p, t-1}$ ) developed by Fan et al. (2007, 2011), who elaborate available statistics and enterprise/household surveys at the provincial and national level. ${ }^{15}$ The marketization variable, measured into a 0 (no marketization) to 10 (full marketization) scale, indicates how each province scores with respect to the others in terms of its progress from the base year towards the realization of a fully fledged market economy. Accordingly, the variation over time of the index has to be interpreted as a change in the relative position of a province with respect to the base year, and not necessarily as an absolute variation of its degree of marketization. The overall index is obtained from a principal component analysis applied to 23 normalized indicators covering five major areas (i.e., fields) where state control is typically exercised in a non-market economy: (a) Government-market relations, and in particular the size of the government in the regional economy (budgetary expenses as share of GDP, and public employees as share of the population), the non-tax financial burden of enterprises (as ratio over their sales), farmers tax and non-tax burdens (as share of their income), the share of working time spent by entrepreneurs to deal with public officials ${ }^{16}$; (b) the composition and evolution of the local economic structure (in terms of output, investments and urban employment), mainly concerning the growth of the non-state sector and the reform of the state enterprises; (c) the extent of interregional trade barriers (i.e., local trade protection) and price controls, regarding the product/commodity markets; (d) the development of the markets for the factors of production (e.g., labor, bank credit, technology, capital), and their territorial mobility ${ }^{17}$; (e) the quality of the legal and judiciary framework as well as the development of services associated with the functioning of advanced economic institutions (in particular, intermediaries such as law firms, accounting offices, independent auditing offices, and the like). ${ }^{18}$ The overall index is based on the equally weighted results obtained by each province in each of the five field indices.

In the empirical analysis the overall index and each of the five field indices will be considered: the field indicators deserve to be observed separately as they evolved differently across regions and over time. ${ }^{19}$ For instance, the improvements regarding the share of the private sector in the economy have proceeded relatively faster than those in the government-market relationship and factor markets. At the same time, while certain provinces have improved in all dimensions, others have recorded more mixed results. This degree of time and regional variation, on which we shall come back below, is important as it provides the variability needed to identify the parameters of interest and the channels at work.

To account for agglomeration externalities, we consider both a proxy for localization externalities associated with specialization and a proxy for urbanization economies. Fracasso and Vittucci Marzetti (2018) show that the specialization index, as well as the location quotient, can be employed to capture localization externalities only to the extent that the size of the local economy is also included in the empirical specification. Accordingly, we consider standard measures for each of these two dimensions of agglomeration in all our estimations (see Beaudry \& Schiffauerova, 2009; Melo et al., 
2009). It follows that localization economies are captured via the specialization ratio, that is the ratio of the value of local sales of industry $s$ in province $p$ over the total value of the local sales in province $\left(\right.$ Specialization $\left._{p s, t-1}\right),{ }^{20}$ whereas urbanization economies are proxied by a measure of the size of the local economy, namely total population $\left(\right.$ Population $_{p, t-1}$ ) in province $p$. To control for agglomeration dis-economies, in the estimation we include also the (logarithm of) average provincial wages per worker (Wage ${ }_{p, t-1}$ ), with a view to controlling for time-varying costs of production in the region associated with agglomeration diseconomies.

To analyse the impact of human capital, we introduce a measure of the coverage of the more advanced cycles of the educational system at the provincial level in China, that is the ratio of the number of students in higher education over the number of students in primary education (Student Ratio ${ }_{p, t-1}$ ), as done in Bin, Chen, Fracasso, and Tomasi (2018). As a robustness check, in Section 4.3 we use the value of public expenditures in education and culture $\left(\operatorname{GovExpEdu}_{p, t-1}\right)$, as this may help to capture other local knowledge-generating institutions.

The relative importance of innovation activities at the local level is calculated with an output measure, that is, the number of patents granted in the province (\# Patents Granted $\left.{ }_{p, t-1}\right) .^{21}$ Alternatively, in Section 4.3, we consider an input measure, namely the value of public expenditures in science and innovation at the provincial level (GovExpScience $\left.{ }_{p, t-1}\right)$. As discussed in Section 2, green innovation appears particularly conducive to labour growth and, accordingly, we include a variable measuring investment in anti-pollution schemes (or alternatively its ratio over GDP) at the provincial level (Antipollution Investment ${ }_{p, t-1}$ ) to capture this channel. Alternatively, in Section 4.3, we employ a variable that captures the effectiveness of the measures to protect the environment in terms of accidents (Pollution Accidents $\left.{ }_{p, t-1}\right) .^{22}$

In all the specifications, we include two additional province level variables to control for geographical aspects whose omission might bias our estimates. Specifically, we add the provincial GDP per capita $\left(\mathrm{GDPpc}_{p, t-1}\right)$ so as to distinguish the specific impact of the regional factors from the fact that provinces are at differentiated stages of economic development, and the share of private firms in the province at a specific point in time (\% Private Firms ${ }_{p, t-1}$ ) because China witnessed, during the period under analysis, a fast process of transformation characterized by a decline in the role of state-owned enterprises and collective firms and by a massive entry of private enterprises (often replacing previously established public firms). ${ }^{23}$ As state-owned firms differ from private companies, with the former showing lower profitability, slower growth and softer budget constraints (Bai, Lu, \& Tao, 2006; Guariglia, Liu, \& Song, 2011; Yu et al., 2017), we control for differences across provinces in the speed and intensity of the restructuring of stateowned companies. The possible confounding effect that companies embedded in local environments with few private firms tend to grow less is captured in our empirical model by controlling for the percentage of private firms within each province, besides considering the ownership of the individual firm. Notably, the decision to include these two additional provincial variables is very conservative in that it helps to control for possible unobservable time-varying provincial effects, but comes at the cost of absorbing part of the explanatory power of the main variable of interest (i.e., the level of marketization).

Panel A of Table 2 lists all the regional variables used throughout our empirical analysis and the data sources. In estimating the employment growth equation, all variables, with the exception of the dummy variables and those in percentages, are expressed in natural logs. To limit possible endogeneity issues, all the explanatory variables are calculated at the beginning of the growth period $(t-1)$. It is worth noticing that endogeneity problems in firm-level studies investigating the impact of aggregate factors (either at the regional or at the industry level) tend to be more mild than in regional-level 
TA B L E 2 Variables name and definition

\begin{tabular}{|c|c|c|c|}
\hline Concept & Variable & Description & Data source \\
\hline \multicolumn{4}{|c|}{ PANEL A-Province-level variables } \\
\hline Marketization & Marketization Index $_{p, t-1}$ & $0-10$ scale & Fan et al. (2011) \\
\hline Sub-index 1 & $\begin{array}{l}\text { Government-market rela- } \\
\text { tionship }_{p, t-1}\end{array}$ & $0-10$ scale & Fan et al. (2011) \\
\hline Sub-index 2 & $\begin{array}{l}\text { Development of private } \\
\text { economy }_{p, t-1}\end{array}$ & $0-10$ scale & Fan et al. (2011) \\
\hline Sub-index 3 & $\begin{array}{l}\text { Development of product } \\
\text { market }_{p, t-1}\end{array}$ & $0-10$ scale & Fan et al. (2011) \\
\hline Sub-index 4 & $\begin{array}{l}\text { Development of factor } \\
\text { market }_{p, t-1}\end{array}$ & $0-10$ scale & Fan et al. (2011) \\
\hline Sub-index 5 & $\begin{array}{l}\text { Development of legal } \\
\text { environment }_{p, t-1}\end{array}$ & $0-10$ scale & Fan et al. (2011) \\
\hline Agglomeration & Specialization $_{p s, t-1}$ & $\begin{array}{l}\text { Ratio of local sales of industry } s \text { in province } \\
p \text { over the total sales production in prov- } \\
\text { ince } p\end{array}$ & NBS \\
\hline Private firms & $\%_{\text {Private Firms }} p, t-1$ & $\begin{array}{l}\text { Ratio of private firms in province } p \text { over } \\
\text { total number of firms in province } p\end{array}$ & NBS \\
\hline Size & Population $_{p, t-1}$ & Total populationin province $p$ & CSY \\
\hline Average income & $\mathrm{GDPpc}_{p, t-1}$ & GDP per capita in province $p$ & CSY \\
\hline Education (a) & HighEducStudent $_{p, t-1}$ & $\begin{array}{l}\text { Ratio of students in higher education over } \\
\text { those in primary education in province } p\end{array}$ & CSY \\
\hline Education (b) & $\mathrm{GovExpEdu}_{p, t-1}$ & $\begin{array}{l}\text { Public expendituresfor education in prov- } \\
\text { ince } p\end{array}$ & CSY \\
\hline Innovation (a) & \# Patent Granted ${ }_{p, t-1}$ & Number of patents granted in province $p$ & CSY \\
\hline Innovation (b) & GovExpScience $_{p, t-1}$ & $\begin{array}{l}\text { Public expenditures for science and innova- } \\
\text { tion in province } p\end{array}$ & CSY \\
\hline Environment (a) & $\begin{array}{l}\text { Antipollution } \\
\text { Investment }_{p, t-1}\end{array}$ & $\begin{array}{l}\text { Investment in anti-pollution schemes in } \\
\text { province } p\end{array}$ & CSY \\
\hline Environment (b) & \# Pollution Accidents ${ }_{p, t-1}$ & Number of pollution accidents in province $p$ & CSY \\
\hline Factor costs & Wage $_{p, t-1}$ & Average wages per worker in province $p$ & CSY \\
\hline \multicolumn{4}{|c|}{ PANEL B-Firm-level variables } \\
\hline Size & $\mathrm{Empl}_{f, t-1}$ & Number of employees & NBS \\
\hline Age & $\operatorname{Age}_{f, t-1}$ & Year-Foundation year & NBS \\
\hline Productivity & $\operatorname{TFP}_{f, t-1}$ & $\begin{array}{l}\text { Estimate of a parametric production func- } \\
\text { tion (Olley \& Pakes, 1996) }\end{array}$ & NBS \\
\hline $\begin{array}{l}\text { Financial } \\
\text { conditions }\end{array}$ & Leverage $_{f, t-1}$ & Ratio between total debt and total assets & NBS \\
\hline Trade & Export Status $_{f, t-1}$ & Dummy variable for exporter & NBS \\
\hline Innovation & NewProduct $_{f, t-1}$ & $\begin{array}{l}\text { Percentageshare of output related to new } \\
\text { products }\end{array}$ & NBS \\
\hline Ownership & Private $_{f, t-1}$ & Dummy variable for private firms & NBS \\
\hline
\end{tabular}

Note: The variables are derived by the firm-level data set of the National Bureau of Statistics (NBS) or by the Chinese Statistical Yearbooks (CSY). 
studies. This is particularly true when the dimensions of the regions is sufficiently large to exclude that a single company can drive the regional variable, thereby preventing reverse causality problems.

Given our focus on the regional determinants of firm employment growth, some information about the variability of the main regressors is of particular note. Table 3 provides some descriptive statistics regarding the regional institutional and economic variables used in the empirical analysis. We exploit the variability over time and across provinces to identify the impact that local features have on firm employment growth. By looking at the mean and at the standard deviation one can easily compute the coefficient of variation for the main variables of interest, detecting a high level of variability in the data. As far as the overall marketization index is concerned, as also discussed by Fan et al. (2017, 2018), the process towards a market-oriented economy was characterized by highly heterogeneous provincial patterns, even though all provinces made some progress over time. In particular, progress in market-oriented reforms was geographically uneven, with the eastern coastal areas maintaining the lead over some central and western provinces, scoring relatively low levels and more limited improvements. As Figure A1 shows, all the five field indices in 2007 were still far below 10, although higher than in 1999, and this was mainly due to the limited advances in a number of provinces lagging behind. Figure A1 offers a cursory look at the relationship between the (weighted) average of firm growth rates at the provincial level and a number of the provincial-level variables included in the regression. Taking the average values of the variables over the entire time period, the figure reports unconditional univariate regressions exploiting the cross-province variability. Together with Table A1, Figure A2 allows for a visual inspection of the regional variability in the sample. In all the plots, a positive correlation between firms' average growth rates and provincial factors emerges: the average firm growth rates tend to be higher in those provinces exhibiting a better position in terms of marketization, larger anti-pollution investment, higher investment in education and in innovation activities.

TA B L E 3 Descriptive statistics

\begin{tabular}{|c|c|c|c|c|}
\hline Variable & Unit measure & Mean & Median & $S D$ \\
\hline Marketization $_{p}$ & {$[0-10]$} & 5.52 & 5.19 & 2.09 \\
\hline Government-market relationship $_{p}$ & {$[0-10]$} & 6.91 & 7.04 & 2.07 \\
\hline Development of private economy $y_{p}$ & {$[0-10]$} & 5.70 & 5.38 & 3.08 \\
\hline Development of product markets ${ }_{p}$ & {$[0-10]$} & 7.32 & 7.38 & 1.91 \\
\hline Development of factor market $p_{p}$ & {$[0-10]$} & 3.96 & 3.29 & 2.38 \\
\hline Development of legal environment ${ }_{p}$ & {$[0-10]$} & 4.46 & 3.81 & 2.47 \\
\hline Specialization $_{p s}$ & $\%$ & 6.19 & 5.69 & 1.94 \\
\hline Population $_{p}$ & 10,000 persons & $4,104.72$ & $3,759.5$ & $2,615.1$ \\
\hline Wage $_{p}$ & $\begin{array}{l}\text { Wages per } \\
\text { capita-Yuan }\end{array}$ & $13,630.9$ & $12,423.3$ & $6,437.6$ \\
\hline$\%$ HigEducStudent $_{p}$ & $\%$ & 15.6 & 8.99 & 20.71 \\
\hline \# Patents $p_{p}$ & \# & 4,317 & 1999 & 6,993 \\
\hline Antipollution Investment ${ }_{p}$ & 10,000 Yuan & 92,889 & 56,742 & 103,899 \\
\hline $\mathrm{GDPpc}_{p}$ & Yuan & $12,597.9$ & $9,394.5$ & $10,359.5$ \\
\hline$\%$ Private Firms $p$ & $\%$ & 58.79 & 54.33 & 13.28 \\
\hline
\end{tabular}

Note: Table provides descriptive statistics (mean, median and standard deviation) of the variables used in the empirical analysis. 


\subsection{Firm-level control variables}

To better identify the impact of regional determinants and address possible firm-level endogeneity problems, we control for a set of firm-level variables that previous studies have identified as critical features (internal to the firm) of growth. Panel B of Table 2 presents the name and the definition of each firm-level characteristic used in the empirical analysis.

According to Coad and Holzl (2012), the literature has found evidence that firm size has an impact on firm growth and employment creation. Hence, we include in the estimation the number of employees $\left(\mathrm{Empl}_{f, t-1}\right)$ in the firm at the beginning of the period. As small enterprises are often relatively young, several authors have shown that both firm size and firm age are negatively associated with growth, even once both factors are controlled for simultaneously. We therefore include among the covariates also firms' age $\left(\operatorname{Age}_{f, t-1}\right)$. Notably, because of the firm-level fixed effects in the main specification, this variable captures firm-specific trends; in the auxiliary regression with regional fixed effects, instead, also the cross-sectional variability contributes to the identification of the parameter of this variable.

In addition to these demographic features of the firm (i.e., initial size and age), we include another important firm attribute, namely the level of total factor productivity (TFP), estimated via a parametric production function à la Olley and Pakes (1996) on an industry-by-industry case. ${ }^{24}$ We believe that the inclusion of this covariate is a conservative choice as the impact of productivity on firm employment growth is not unequivocally established in the literature. It is a conservative solution because, as also argued by Yu et al. (2017), it is plausible that the observed firm heterogeneity in terms of productivity might have some relationship with corporate growth and in such a case it is appropriate to control for it so as to reduce omitted variable problems. The possibility that the level of productivity and the growth of employment are related is suggested by those studies showing that the observed improvement in within-province allocative efficiency in China over time may stem from the relatively faster growth in size of the more productive firms (Bin et al., 2018; Brandt et al., 2012; Fan et al., 2018); if this is the case, for instance due to the possibility for the most productive Chinese companies to gain market shares abroad and expand their production, a positive relationship between the variables would likely emerge. ${ }^{25}$ Although the firm-level variables entering the empirical specification are mainly treated as controls and not as covariates of interest, we choose not to disregard any trait of the firm that might potentially contribute to determine its growth.

Also the financial conditions of the firm and its exposure to credit rationing have been considered as critical factors for firm growth (Coad, 2010). Yet, the literature on financial constraints has not produced unambiguous results on the relationship between financial conditions and firm growth (Bottazzi, Secchi, \& Tamagni, 2008; Coad, 2007; Dosi, 2008). To encompass a measure of the firm's financial conditions, as done by Fagiolo and Luzzi (2006) and Bottazzi, Secchi, and Tamagni (2014) among others, we calculate the firm leverage as the (lagged) ratio between the firms' total debt and total assets (Leverage f $t,-1_{1}$ ); this follows what done, for instance, by Guariglia et al. (2011) and Poncet, Steingress, and Vandenbussche (2010). ${ }^{26}$

Another firm-level determinant of firm growth regards its exposure to global markets: the available evidence suggests that internationalized firms (either through exports or foreign investments), tend to growth faster. Following Cintio, Ghosh, and Grassi (2017) and Sousa, Rueda-Cantuche, Arto, and Andreoni (2012), who provide evidence about the relatively higher growth of exporting firms, we employ a dummy variable identifying firms that are active in international markets through exporting $\left(\right.$ Export Status $\left._{f, t-1}\right)$.

Finally, the literature on industrial dynamics has found that firm innovation is associated with firm growth (see Dachs \& Peters, 2014; Harrison, Jaumandreu, Mairesse, \& Peters, 2014, for an overview and original findings). Notably, while in principle firm innovation impacts positively on sales and 
profits, its theoretical relationship with firm employment is not clear-cut, due to possibility of technological unemployment effects. Empirical studies have yielded mixed results too, depending on the type of innovation product or process considered (see Bogliacino \& Pianta, 2010; Coad, Segarra, \& Teruel, 2016; Cucculelli \& Ermini, 2012; Hall, Lotti, \& Mairesse, 2008, 2009; Lachenmaier \& Rottmann, 2011, among others). Taking stock of this large body of research, we encompass among the covariates a measure of the firm's involvement in innovation activities, measured as the share of output related to the Introduction of new products (NewProduct ${ }_{f, t-1}$ ).

As explained, although the results regarding the estimated coefficients of these firm-level variables are interesting per se, the focus of our analysis falls on the impact of regional factors on firm employment growth. The inclusion of firm-level determinants is motivated mainly by the recognition that neglecting them could create possible omitted variables problems. This very same concern motivates also the inclusion of firm-level fixed effects capturing any time-invariant unobserved heterogeneity at the firm level, as discussed in Section 4. Such fixed effects are thus useful to address possible endogeneity of firm characteristics, and reduces even further the possibility of endogeneity problems for the estimated coefficients of the regional factors of interest. Even though the characteristics of individual firms can hardly influence regional variables calculated at the provincial level in China, we err on the side of caution by including both (lagged) firm-level variables as controls and firm-level fixed effects for capturing unobserved heterogeneity. This cautionary fixed effects approach comes as a cost, that is the impossibility to exploit fully the variability across firms for the identification of the parameters to estimate. As shown in Section 4, the estimates obtained by an auxiliary regression encompassing industry and province fixed effects deliver results that are qualitative similar to those obtained using firm-level fixed effects. Moreover, an additional regression where marketization is instrumented in a two-stage least-squares estimation shows that the results are robust across estimation methods. ${ }^{27}$

\section{4 | THE ROLE OF MARKETIZATION AND REGIONAL ECONOMIC FACTORS: THE EMPIRICAL ANALYSIS}

\section{1 | Main findings}

To evaluate the impact of the regional factors on firm employment growth, we estimate a simple growth model that incorporates the regional variables of interest and, as controls, the firm-level covariates. Accordingly, the empirical model to estimate looks like follows.

$$
\Delta \ln \operatorname{Empl}_{f, t}=\beta_{0}+\beta_{1} \ln \operatorname{Empl}_{f, t-1}+\beta_{2} X_{f, t-1}+\beta_{3} Z_{p, t-1}+\epsilon_{f, t}
$$

where the $\Delta \ln \operatorname{Empl}_{f, t}$ is the employment growth rate of firm $f$ at time $t$ and $\ln \operatorname{Empl}_{f, t-1}$ is the level of employment at the beginning of the period. $X_{f, t-1}$ is the vector of firms' characteristics at the beginning of the period (used a controls for the internal determinants) while the vector $Z_{p, t-1}$ includes the regional factors listed in Table 2 and discussed in Section 2. The error term $\epsilon_{f, t}$ includes a time-specific component accounting for possible business cycle effects common to all units (that we control for by including time dummies in all specifications), and a firm-level time-invariant unobserved component, that we account for by introducing firm-level fixed effects. ${ }^{28}$ Robust standard errors allowing for clustering of the residuals at the province industry level are computed in all the estimations and the results are robust to alternative treatments of the error terms, such as clustering at firm level or at the province level. 
Before presenting the results from the estimations, it is worth discussing briefly possible endogeneity issues due to omitted variables, measurement errors and reverse causation. As anticipated in the previous Section, we believe that endogeneity may be a limited problem in our analysis for a number of reasons. First, the set of firm characteristics included as controls in the regressions captures those factors that, according to the literature, are the most important internal determinants of firm growth, thereby reducing the likelihood of firm-level omitted variable problems. Second, both the firm-level controls and the regional variables enter in the regression with a lag, that reduces simultaneity (and reverse causality problems). Moreover, in the econometric specifications possible differences in unobserved heterogeneity are accounted for by the inclusion of a firm-specific time-invariant component in the error term (i.e., the fixed effect), as suggested by Bojas and Barbosa (2015); this latter captures any unobserved time-invariant effects that our explanatory variables are not able to control for. Finally, the analysis mainly focuses on the impact of regional factors and, given the dimensions of the Chinese provinces, an individual firm can hardly determine the evolution of the entire region-level covariates, which would be a problem of reverse causality. This is confirmed by one of our robustness checks in which we restrict the analysis on a sample with only small companies, whereby the possibility of reserve causality is ruled out by construction. Similar conclusions stem from an additional robustness check, whereby firm-level fixed effects are removed and the marketization variable is instrumented with its second lag: also in this case, the results of interest are not affected.

Table 4 gathers the empirical results from the estimation of specifications including one potential regional determinant at the time, together with all the firm-level variables used as controls. All the parameters are statistically significant and with the expected signs.

Column 1 reports the results for the overall marketization index, our main variable of interest. A positive and significant coefficient signals that companies tend to growth faster where institutions are more developed and more in line with the transition towards a market-based economy. This suggests that the faster economic and employment growth in the institutionally more advanced regions is also due to the higher growth within the incumbent firms, in addition to the favourable compositional effects associated with the entry and exit of companies shown, for instance, by Guo, He, and Li (2016) and Zhou and Hall (2017), among other contributions reviewed in the Introduction.

Two measures of agglomeration appear in columns (2) and (3), but in the latter we also consider the average value of local wages so as to capture a specific type of agglomeration dis-economies. All the estimated coefficients are in line with expectations and consistent across the specifications. These findings confirm that companies located in areas where economic specialization is greater and the overall size of the economic activities is larger do benefit from positive spillovers which, in turn, favour employment growth. This effect is moderated by the increasing cost of labour where demand is higher: this is in line with economic intuition and with previous results regarding the non-linear effects of agglomeration externalities (see Cainelli, Fracasso, \& Vittucci Marzetti, 2015; Martin, Mayer, \& Mayneris, 2011).

Column 4 reports the estimated coefficients when the ratio of the number of students in higher education over those in primary education (Student Ratio ${ }_{p, t-1}$ ) is included in the estimation. As this variable captures the relative coverage of the more advanced cycles in education, a positive and significant coefficient can be interpreted as a sign that employment growth is larger where the availability of educated labour is more abundant, in line with the presence of knowledge spillovers in areas populated by skilled workers and consistent with the upgrading process ongoing in many Chinese companies. In columns (5) and (6), we include, one at the time, two additional variables: the number of patents granted in the province (\# Patents $\operatorname{Granted}_{p, t-1}$ ), and the local investment in anti-pollution schemes (Antipollution Investment $t_{p, t-1}$ ). Both variables enter the equation with a positive and statistically significant coefficient, thereby confirming that firms benefit from locating in areas where research and 
TA B LE 4 Regional- and firm-level determinants of firm employment growth

\begin{tabular}{|c|c|c|c|c|c|c|}
\hline \multirow[b]{2}{*}{ Dep. var. } & \multicolumn{6}{|l|}{$\underline{\Delta \ln \mathbf{E m p l}_{f, t}}$} \\
\hline & (1) & (2) & (3) & (4) & (5) & (6) \\
\hline Marketization Index $x_{p, t-1}$ & $\begin{array}{l}.030 * * * \\
(.006)\end{array}$ & & & & & \\
\hline Specialization $_{p s, t-1}$ & & $\begin{array}{l}.332 * * * \\
(.070)\end{array}$ & $\begin{array}{l}.336^{* * *} \\
(.070)\end{array}$ & & & \\
\hline ln Population $_{p, t-1}$ & & $\begin{array}{l}.542 * * * \\
(.072)\end{array}$ & $\begin{array}{l}.469 * * * \\
(.074)\end{array}$ & & & \\
\hline $\ln$ Wage $_{p, t-1}$ & & & $\begin{array}{l}-.194 * * * \\
(.051)\end{array}$ & & & \\
\hline$\%$ HighEducStundent $_{p, t-1}$ & & & & $\begin{array}{l}.165^{* * *} \\
(.063)\end{array}$ & & \\
\hline ln \# Patent Granted ${ }_{p, t-1}$ & & & & & $\begin{array}{l}.095^{* * * *} \\
(.014)\end{array}$ & \\
\hline $\begin{array}{l}\text { In Antipollution } \\
\text { Investment }_{p, t-1}\end{array}$ & & & & & & $\begin{array}{l}.016^{* *} \\
(.006)\end{array}$ \\
\hline $\ln \mathrm{GDPpc}_{p, t-1}$ & $\begin{array}{l}.167 * * * \\
(.056)\end{array}$ & $\begin{array}{l}.209^{* * *} \\
(.057)\end{array}$ & $\begin{array}{l}.259^{* * *} \\
(.062)\end{array}$ & $\begin{array}{l}.214 * * * \\
(.062)\end{array}$ & $\begin{array}{l}.141^{* *} \\
(.057)\end{array}$ & $\begin{array}{l}.213^{* * *} \\
(.063)\end{array}$ \\
\hline$\%$ Private Firms $s_{p, t-1}$ & $\begin{array}{l}.090^{* * * *} \\
(.010)\end{array}$ & $\begin{array}{l}.100 * * * \\
(.009)\end{array}$ & $\begin{array}{l}.103^{* * *} \\
(.009)\end{array}$ & $\begin{array}{l}.101^{* * *} \\
(.009)\end{array}$ & $\begin{array}{l}.094 * * * \\
(.009)\end{array}$ & $\begin{array}{l}.102^{* * *} \\
(.009)\end{array}$ \\
\hline $\ln \operatorname{TFP}_{f, t-1}$ & $\begin{array}{l}.074 * * * \\
(.003)\end{array}$ & $\begin{array}{l}.075^{* * *} \\
(.003)\end{array}$ & $\begin{array}{l}.075^{* * *} \\
(.003)\end{array}$ & $\begin{array}{l}.074 * * * \\
(.003)\end{array}$ & $\begin{array}{l}.074 * * * \\
(.003)\end{array}$ & $\begin{array}{l}.073^{* * *} \\
(.003)\end{array}$ \\
\hline Export Status $_{f, t-1}$ & $\begin{array}{l}.060 * * * \\
(.004)\end{array}$ & $\begin{array}{l}.061^{* * * *} \\
(.004)\end{array}$ & $\begin{array}{l}.062 * * * \\
(.004)\end{array}$ & $\begin{array}{l}.060 * * * \\
(.004)\end{array}$ & $\begin{array}{l}.060 * * * \\
(.004)\end{array}$ & $\begin{array}{l}.060 * * * \\
(.004)\end{array}$ \\
\hline$\%$ NewProduct $_{f, t-1}$ & $\begin{array}{l}.055^{* * *} \\
(.010)\end{array}$ & $\begin{array}{l}.055^{* * *} \\
(.010)\end{array}$ & $\begin{array}{l}.055^{* * *} \\
(.010)\end{array}$ & $\begin{array}{l}.057 * * * \\
(.010)\end{array}$ & $\begin{array}{l}.053 * * * \\
(.010)\end{array}$ & $\begin{array}{l}.058^{* * * *} \\
(.010)\end{array}$ \\
\hline $\ln \operatorname{Empl}_{f, t-1}$ & $\begin{array}{l}-.698^{* * * *} \\
(.019)\end{array}$ & $\begin{array}{l}-.699 * * * \\
(.019)\end{array}$ & $\begin{array}{l}-.699 * * * \\
(.019)\end{array}$ & $\begin{array}{l}-.695 * * * \\
(.018)\end{array}$ & $\begin{array}{l}-.698 * * * \\
(.019)\end{array}$ & $\begin{array}{l}-.697 * * * \\
(.019)\end{array}$ \\
\hline Leverage $_{f, t-1}$ & $.006(.006)$ & $.004(.006)$ & $.004(.006)$ & $.006(.006)$ & $.006(.006)$ & $.006(.006)$ \\
\hline $\operatorname{Age}_{f, t-1}$ & $\begin{array}{l}.035^{* * *} \\
(.003)\end{array}$ & $\begin{array}{l}.031 * * * \\
(.003)\end{array}$ & $\begin{array}{l}.031 * * * \\
(0.003)\end{array}$ & $\begin{array}{l}.036^{* * *} \\
(.003)\end{array}$ & $\begin{array}{l}.034 * * * \\
(.003)\end{array}$ & $\begin{array}{l}.037 * * * \\
(.003)\end{array}$ \\
\hline Firm FE & Yes & Yes & Yes & Yes & Yes & Yes \\
\hline Year FE & Yes & Yes & Yes & Yes & Yes & Yes \\
\hline$N$ & $1,114,845$ & $1,115,136$ & $1,115,136$ & $1,115,136$ & $1,115,136$ & $1,114,644$ \\
\hline adj. $R^{2}$ & 0.326 & 0.327 & 0.327 & 0.326 & 0.326 & \\
\hline
\end{tabular}

Note: Table reports the regressions for the determinants of firms' growth, 1998-2007. Results show the coefficients with standard errors (in parenthesis) clustered at the province-industry level: $* * *<.01 ; * *<.05$.

innovation efforts are higher. This suggests that the inevitable downsizing of a few large state-owned companies has been partly compensated by the increase in labour demand resulting from activities directed to innovate and upgrade the industrial system. 
In column (1) of Table 5 we report the results obtained by introducing all the regional factors at the same time. The results in Table 4 are confirmed and so is the importance of the level of marketization and other regional factors for firm employment growth. This shows that the marketization variable captures specific aspects that pertain to the market-oriented transformation of the local economies in China, once other regional factors are simultaneously considered. This also shows that all the theoretical channels identified by reference to the literature and to economic intuition in Section 2 are indeed at work, even when we control for all of them at the same time. This implies that these factors operate through different, though possibly overlapping, mechanisms.

The estimated coefficients provide evidence that firm-level factors are relevant to explain firm employment growth, as reported by Coad and Holzl (2012) in their review of studies on the internal determinants of firm growth focusing on non-Chinese enterprises. Ceteris paribus, the more productive the firms, the greater the employment growth, in line with the results in Moschella et al. (2019); similarly, and also in line with Moschella et al. (2019), firms more exposed to foreign markets and more innovative tend to expand employment more. Conversely, employment growth is negatively related to the firm size at the beginning of the period, as commonly found in the literature. ${ }^{29}$ Due to the presence of firm fixed effects, the variable for the age of the firms captures the impact of ageing; accordingly, the estimates suggest that employment growth increases (on average) while the firms get older. Only the parameter for firm leverage does not appear to be statistically significant: the empirical evidence does not help to solve the theoretical ambiguity regarding the possible sign of the coefficient.

To compare the relative importance of the different covariates, in column (2) of Table 5 we report the beta coefficients of standardized variables. The estimates suggest that the overall size of the local economy and the average wage level, among the regional factors, and the initial size of the enterprise, among the internal factors, are the most important determinants of the variation in firm employment. Among the regional factors, the coefficient of the marketization index is certainly non-negligible: this confirms that incumbent firms are positively affected by well-functioning economic institutions and that firms' employment strategies reflect the evolution of the institutional context. This represents an important insight for policy makers in China interested in the effects that institutional quality has on industrial change: we find that well-functioning institutions that facilitate the transition towards a market economy do not only spur greater dynamism, but also favour labour absorption by the incumbent firms.

In column (3) of Table 5 we show that, after dropping firm-level fixed effects and adding province and industry fixed effects, the results do not change much. The coefficient of the size of the economy becomes not statistically significant different from zero with this alternative set of fixed effects: this can be explained by the fact that, once province fixed effects are included, there is no much variability left in this agglomeration series. This alternative specification for the fixed effects allows to include also one firm-level determinant that could not be assessed before, namely a dummy variable for the foreign owned enterprises, Foreign $n_{f, t-1}$. The literature has shown that foreign-owned companies experience difficulties in access to external financing and resources but, at the same time, benefit from foreign knowledge, know-how, networking, and the like. Similarly, it is not clear whether domestic-owned firms bear stronger political pressures to employ more local workers or whether foreign-owned companies try to please the local authorities by absorbing more labour force. It follows that whether foreign ownership either facilitates or hampers firm employment growth remains an empirical issue. The estimated coefficient confirms that foreign-owned firms tend to expand employment relatively more, in line with anecdotal evidence regarding the evolution of the companies located in the coastal areas in China, typically involved in trade activities and often (at least partially) owned by foreign investors. 
T A B L E 5 Regional- and firm-level determinants of firm employment growth: Multivariate

\begin{tabular}{|c|c|c|c|c|}
\hline \multirow[b]{3}{*}{ Dep. var. } & \multicolumn{4}{|c|}{$\Delta \ln \operatorname{Empl}_{f, t}$} \\
\hline & \multirow[b]{2}{*}{ (1) } & \multirow[b]{2}{*}{ (2) } & \multirow{2}{*}{$\frac{\text { OLS }}{(3)}$} & \multirow{2}{*}{$\frac{\text { IV }}{(4)}$} \\
\hline & & & & \\
\hline \multirow{2}{*}{ Marketization Index $_{p, t-1}$} & $.021 * * *$ & $.080 * * *$ & $.004 * *$ & $.020 * * *$ \\
\hline & $(.008)$ & $(.031)$ & $(.002)$ & $(.009)$ \\
\hline \multirow{2}{*}{ Specialization $_{p s, t-1}$} & $.334 * * *$ & $.034 * * *$ & $.134 * * *$ & $0.123 * * *$ \\
\hline & $(.070)$ & (.007) & $(.012)$ & $(.028)$ \\
\hline \multirow{2}{*}{ ln Population P $t-1$} & $.246^{* * *}$ & $.268 * * *$ & -.003 & -.012 \\
\hline & $(.066)$ & $(.072)$ & $(.016)$ & $(.041)$ \\
\hline \multirow[t]{2}{*}{$\ln \mathrm{Wage}_{p, t-1}$} & $-.333 * * *$ & $(.058)$ & $(.015)$ & $(.074)$ \\
\hline & $(.077)$ & $.065^{* * *}$ & $.293 * * *$ & $.363^{* * *} *$ \\
\hline \multirow{2}{*}{$\%$ HighEducStundent $_{p, t-1}$} & $.172 * * *$ & $.065 * * *$ & $.293 * * *$ & $.363 * * *$ \\
\hline & $(.066)$ & $(.025)$ & $(.006)$ & $(.105)$ \\
\hline \multirow{2}{*}{ ln \# Patent Granted ${ }_{p, t-1}$} & $.046 * * *$ & $(.031)$ & $(.004)$ & $.033 * * *$ \\
\hline & $(.016)$ & $.049 * * *$ & $.022 * * *$ & $(.007)$ \\
\hline \multirow[t]{2}{*}{ In Antipollution Investment ${ }_{p, t-1}$} & $.029 * * *$ & $.049 * * *$ & $.002 * * *$ & $.033 * * *$ \\
\hline & $(.007)$ & $(.012)$ & $(.010)$ & $(.007)$ \\
\hline \multirow[t]{2}{*}{$\ln \mathrm{GDPpc}_{p, t-1}$} & $.279 * * *$ & $.302 * * *$ & $.216^{* * *}$ & $.215^{* * *}$ \\
\hline & $(.073)$ & $(.078)$ & $(.010)$ & $(.062)$ \\
\hline \multirow[t]{2}{*}{$\%$ Private Firms $s_{p, t-1}$} & $.094 * * *$ & $.170 * * *$ & $.006^{* *}$ & $.013 * * *$ \\
\hline & $(.009)$ & $(.016)$ & $(.003)$ & $(.006)$ \\
\hline \multirow{2}{*}{ In $\mathrm{TFP}_{f, t-1}$} & $.075 * * *$ & $.154 * * *$ & $.058 * * *$ & $.059 * * *$ \\
\hline & $(.003)$ & $(.006)$ & $(.001)$ & $(.002)$ \\
\hline \multirow[t]{2}{*}{ Export Status $_{f, t-1}$} & $.062 * * *$ & $.050 * * *$ & $.062 * * *$ & $.065^{* * *}$ \\
\hline & $(.004)$ & $(.003)$ & $(.001)$ & $(.005)$ \\
\hline \multirow{2}{*}{$\%$ NewProduct $_{f, t-1}$} & $.052 * * *$ & $.012 * * *$ & $.072 * * *$ & $.057 * * *$ \\
\hline & $(.010)$ & $(.002)$ & $(.004)$ & $(.008)$ \\
\hline \multirow[t]{2}{*}{$\ln \operatorname{Empl}_{f, t-1}$} & $-.698 * * *$ & $-1.465 * * *$ & $-.104 * * *$ & $-.091 * * *$ \\
\hline & $(.018)$ & $(.038)$ & $(.000)$ & $(.005)$ \\
\hline \multirow[t]{2}{*}{ Leverage $_{f, t-1}$} & .004 & .002 & .000 & -.006 \\
\hline & $(.006)$ & $(.003)$ & $(.002)$ & $(.004)$ \\
\hline \multirow{2}{*}{$\mathrm{Age}_{f, t-1}$} & $.030 * * *$ & $.037 * * *$ & $-.005^{* * *}$ & -.004 \\
\hline & $(.003)$ & $(.004)$ & $(.001)$ & $(.002)$ \\
\hline \multirow[t]{2}{*}{ Foreign $_{f}$} & & & $0.050 * * *$ & \\
\hline & & & $(0.002)$ & \\
\hline Firm FE & Yes & Yes & No & No \\
\hline Sector and Province FE & No & No & Yes & Yes \\
\hline Year FE & Yes & Yes & Yes & Yes \\
\hline$N$ & $1,114,644$ & $1,114,644$ & $1,114,346$ & 853,297 \\
\hline
\end{tabular}




\section{TAB LE 5 (Continued)}

\begin{tabular}{|c|c|c|c|c|}
\hline \multirow[b]{3}{*}{ Dep. var. } & \multicolumn{4}{|c|}{$\Delta \ln \operatorname{Empl}_{f, t}$} \\
\hline & \multirow[b]{2}{*}{ (1) } & \multirow[b]{2}{*}{ (2) } & \multirow{2}{*}{$\frac{\text { OLS }}{(3)}$} & \multirow{2}{*}{$\frac{\text { IV }}{(4)}$} \\
\hline & & & & \\
\hline adj. $R^{2}$ & .329 & .329 & .073 & .070 \\
\hline Underidentification stat. & & & & 217.5 \\
\hline ( $p$-value) & & & & $(.000)$ \\
\hline Weak identification stat. & & & & 976.3 \\
\hline
\end{tabular}

Note: Table reports the regressions for the determinants of firms' growth, 1998-2007. Column 1 includes firm and year FE. Column 2 reports stan dardized coefficients. Columns 3 (OLS) and 4 (IV) include province, in dustry and year fixed effects. The IV used in column 4 is the lagged value of Marketization Index $\mathrm{p}, t-2_{2}$ at time $t-2$. Column 4 reports also the under-identification (Kleibergen-Paap LM) and the weak identification (Kleibergen-Paap Wald F) statistics that indicate that our instrument has predictive power. Standard errors (in parenthesis) are clustered at the province-industry level: $* * *<.01 ; * *<.05$.

To resolve any possible doubts regarding the exposure of the main variable of interest to possible endogeneity problems, column (4) of Table 5 explores an alternative estimation method in which we instrument the degree of marketization. Indeed, it could be argued that reforms at the provincial level are determined by considerations of political economy that, in turn, depend on the structure and on the relative performance of the local economy (see for instance Wilson, 2016, who analyses a comprehensive index of governance, partially correlated with the marketization index). To the extent that there is some persistence in such phenomena, taking one-period lag of the marketization variable may not be sufficient to solve entirely the reverse causality problems. Accordingly, column (4) reports the two-stages least-squares estimates where the firm-level fixed effects are removed and the lagged marketization index is instrumented with the second lag of the variables. ${ }^{30}$ The statistical tests support the choice of the instrument and the estimation shows that previous results carry over to this specification as well.

The main results reached so far show that, during this important period for the Chinese economic transition, employment grew faster in those Chinese firms located in provinces making better progress towards establishing a well-functioning market economy, exhibiting higher agglomeration economies, larger investment in education, greater innovation efforts and stronger environmental protection. These findings are derived from a firm-level analysis and they corroborate, and specify, previous results obtained using regional-level studies on the role played by regional factors in affecting growth (Fan et al., 2011, 2018). Besides contributing to the literature on regional economics and growth, our results also show the existence of a micro-macro-connection as to what firm heterogeneity is concerned: heterogeneity in firm employment growth at the country level has to do with a differential growth channel along the regional dimension affecting the development of incumbent firms. This channel adds to those associated with entrepreneurship and industry dynamics, discussed in the Introduction.

\subsection{Sub-indexes and heterogeneous effects}

As mentioned in the Introduction, the overall marketization index summarizes the evolution of five field indices and is measured as the weighted average of 23 indicators. We can exploit the data available for the marketization sub-indices to explore further our previous findings. In Table 6 we repeat the estimation exercise after substituting the overall index with each of the five field indicators: 


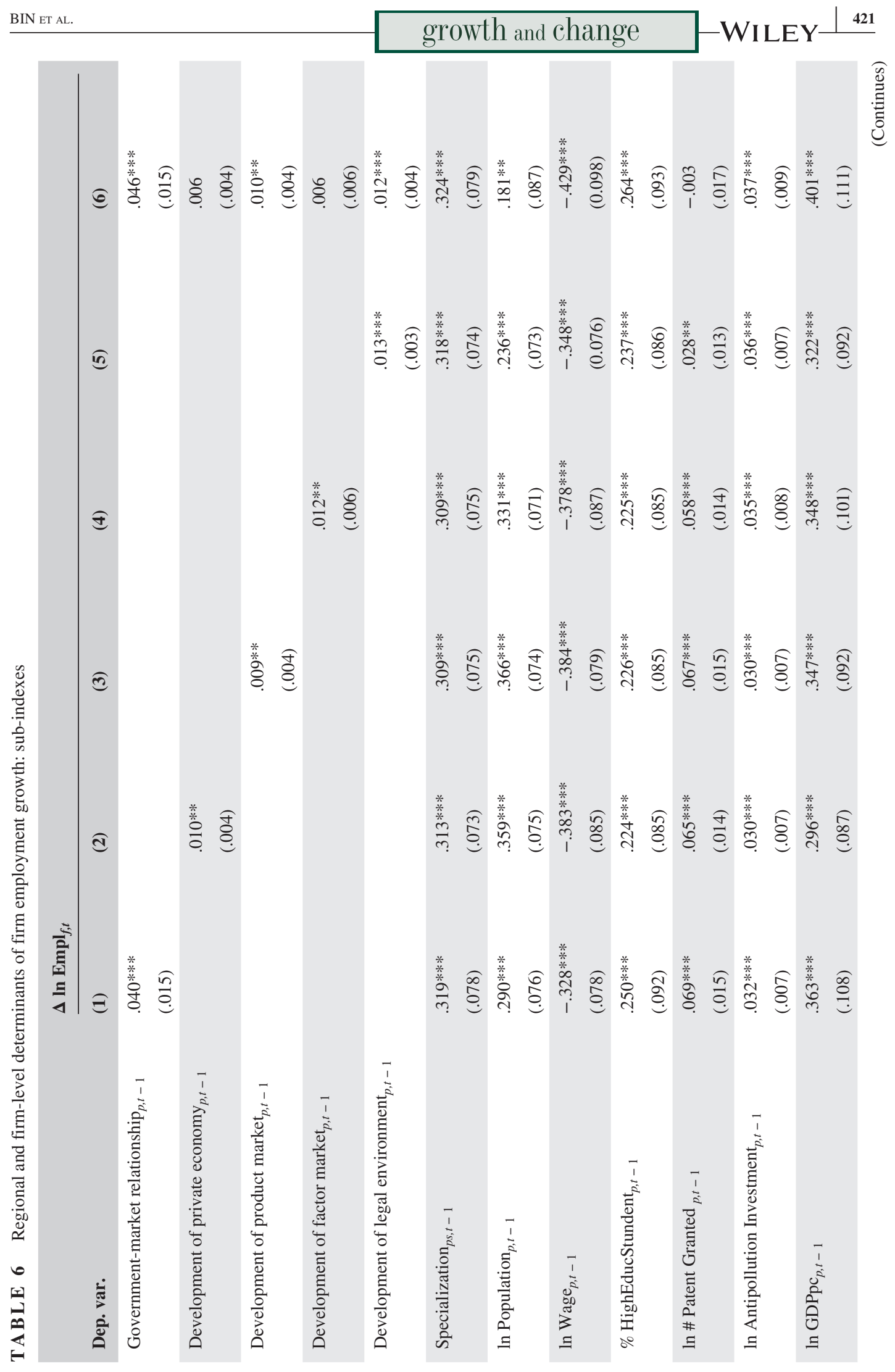




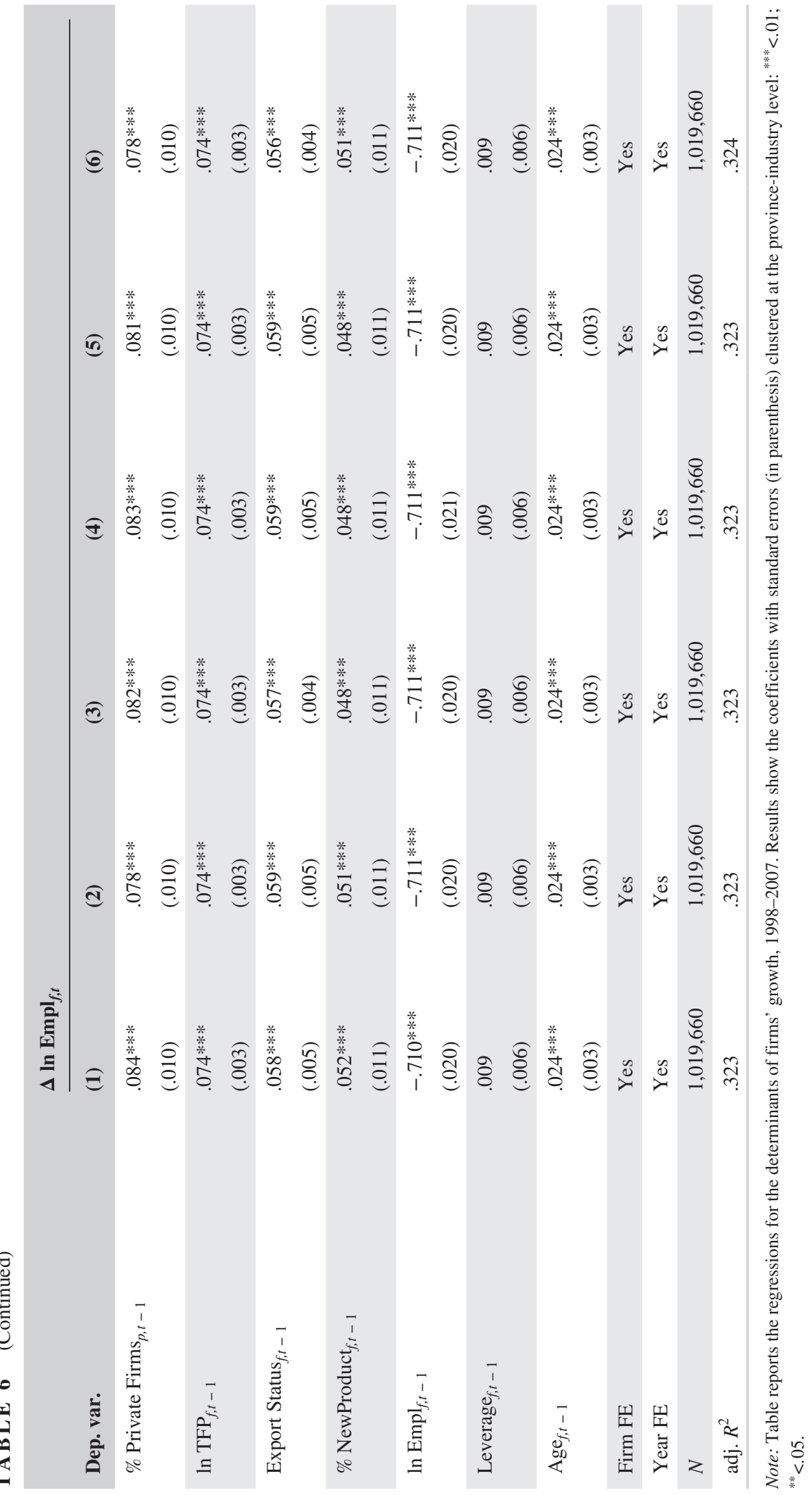


government-market relationship; development of the private sector; development of the product/commodity markets; development of the factor markets; evolution of the legal environment. The estimations confirm the relevance of all the sub-indices because the estimated coefficients are positive and statistically significant, and the parameters of all the remaining regional covariates are almost unaffected. Being built using normalized indicators, these five measures are comparable across the estimations and so are their estimated parameters. The government-market relationship appears as the institutional market-related dimension that has the largest impact on firm employment growth. This is confirmed in column (6) that reports the estimated coefficients when all the sub-indices are simultaneously included. As the government-market relationship index captures various indicators of the pervasiveness of the public intervention in the local economy, this finding suggests that Chinese firms expanded their employment more in those provinces in which they could face lower public interventions and interferences; this implies that privatization, that is the change in ownership of industrial companies, was not the most important dimension of the transition process towards a market economy, at least in terms of firm employment growth. ${ }^{31}$ This result is particularly important if one considers the recent findings by Nakagane and Mitsunami (2018), who argue that the quality of the government-market relationship exercises a positive effect on privatization in China. All in all, at least to the extent that firm employment growth is considered, our findings provide some evidence in favour of the far reaching reform programme implemented by the Chinese authorities in that period.

It is possible that the impact of marketization on firm growth is moderated by other features of the local economy, in particular some of the factors already encompassed in the estimation. For instance, the presence of educated workers may make the quality of the labour market institutions more relevant, the size of local investment in scientific activities may enhance the ability of firms to pricing and marketing the available technologies, and agglomeration may improve business opportunities for the firms that are less subject to government interventions, as higher marketization level and lower restrictions on factors and commodities may boost knowledge spillovers between firms (Zhu et al., 2019). For this reason, in Table 7 we interact three dummy variables identifying the Chinese provinces recording higher than average values for public expenditures (as share of provincial GDP) for education and science (respectively $D_{p, t-1}^{\% \text { Education }}$ and $D_{p, t-1}^{\% \text { Science }}$ ) and higher degree of agglomeration $\left(D_{p, t-1}^{\text {Agglomeration }}\right)$. Results show the existence of some heterogeneity in the relationship between marketization and firm employment growth, but only associated with public expenditures in education and science. This can be explained by the fact that agglomeration economies work through non-pecuniary externalities and that markets play a more limited role.

Overall, these results confirm the robustness of the main findings and provide new evidence on the heterogeneity of the impact of marketization due to the moderation of governments' investment in human capital and science. From a policy viewpoint, this finding calls for a balanced process of development where institutional reforms towards a market economy go hand in hand, for instance, with further investment in human capital and technological progress.

\section{3 | Robustness checks}

In the following we consider a battery of additional exercises aimed at testing the robustness of the results to the adoption of alternative measures of both the dependent and the independent variables, to different sub-samples of firms, and to the inclusion of city-level variables. As discussed in Section 3.1, alternative measures of firm size have been used in the literature. The other most common indicator of size is the value of the current sales. While the number of employees is of particular interest for policy makers and regional economists, sales represent a useful indicator for managers and entrepreneurs. 
T A B L E 7 Regional and firm-level determinants of firm employment growth: heterogeneous effects

\begin{tabular}{|c|c|c|c|}
\hline \multirow[b]{2}{*}{ Dep. var. } & \multicolumn{3}{|c|}{$\Delta \ln \operatorname{Empl}_{f, t}$} \\
\hline & (1) & (2) & (3) \\
\hline \multirow[t]{2}{*}{ Marketization Index $_{p, t-1}$} & $.019 * * *$ & $.021 * * *$ & $.020 * *$ \\
\hline & $(.007)$ & $(.008)$ & $(.008)$ \\
\hline \multirow[t]{2}{*}{$\times D_{p, t-1}^{\% \text { Education }}$} & $.015 * *$ & & \\
\hline & $(.006)$ & & \\
\hline \multirow[t]{2}{*}{$\times D_{p, t-1}^{\% \text { Science }}$} & & $.009 * * *$ & \\
\hline & & $(.003)$ & \\
\hline \multirow[t]{2}{*}{$\times D_{p, t-1}^{\% \text { Agglomeration }}$} & & & .001 \\
\hline & & & $(.004)$ \\
\hline \multirow{2}{*}{$\times D_{p, t-1}^{\% \text { Education }}$} & $.080 * *$ & & \\
\hline & (.039) & & \\
\hline \multirow[t]{2}{*}{$\times D_{p, t-1}^{\% \text { Science }}$} & & $.036 * *$ & \\
\hline & & $(.016)$ & \\
\hline \multirow[t]{2}{*}{$\times D_{p, t-1}^{\% \text { Agglomeration }}$} & & & -.001 \\
\hline & & & $(.044)$ \\
\hline \multirow[t]{2}{*}{ Specialization $_{p s, t-1}$} & $.330 * * *$ & $.330 * * *$ & $.331 * * *$ \\
\hline & $(.071)$ & $(.073)$ & $(.095)$ \\
\hline \multirow[t]{2}{*}{ ln Population P $_{p, t-1}$} & $.215 * * *$ & $.189 * * *$ & $.252 * * *$ \\
\hline & $(.072)$ & $(.072)$ & $(.065)$ \\
\hline \multirow[t]{2}{*}{$\ln$ Wage $_{p, t-1}$} & $-.429 * * *$ & $-.233 * * *$ & $-.333 * * *$ \\
\hline & $(.102)$ & $(.070)$ & $(.077)$ \\
\hline \multirow[t]{2}{*}{$\%$ HighEducStundent $_{p, t-1}$} & $.154 * * *$ & $.179 * * *$ & $.171 * * *$ \\
\hline & $(.059)$ & $(.066)$ & $(.066)$ \\
\hline \multirow[t]{2}{*}{ ln \# Patent Granted ${ }_{p, t-1}$} & $.062 * * *$ & $.049 * * *$ & $.046 * * *$ \\
\hline & $(.015)$ & $(.016)$ & $(.016)$ \\
\hline \multirow[t]{2}{*}{ In Antipollution Investment ${ }_{p, t-1}$} & $.032 * * *$ & $.034 * * *$ & $.029 * * *$ \\
\hline & $(.008)$ & $(.008)$ & $(.007)$ \\
\hline \multirow[t]{2}{*}{$\ln \mathrm{GDPpc}_{p, t-1}$} & $.366 * * *$ & $.226 * * *$ & $.279 * * *$ \\
\hline & $(.095)$ & $(.064)$ & $(.072)$ \\
\hline \multirow[t]{2}{*}{$\%$ Private Firms $s_{p, t-1}$} & $.098 * * *$ & $.097 * * *$ & $.094 * * *$ \\
\hline & $(.008)$ & $(.008)$ & $(.009)$ \\
\hline \multirow[t]{2}{*}{$\ln \operatorname{TFP}_{f, t-1}$} & $.075 * * *$ & $.075 * * *$ & $.075 * * *$ \\
\hline & $(.003)$ & $(.003)$ & $(.003)$ \\
\hline \multirow[t]{2}{*}{ Export Status $_{f, t-1}$} & $.062 * * *$ & $.061 * * *$ & $.062 * * *$ \\
\hline & $(.004)$ & (.004) & $(.004)$ \\
\hline \multirow[t]{2}{*}{$\%$ NewProduct $_{f, t-1}$} & $.052 * * *$ & $.047 * * *$ & $.052 * * *$ \\
\hline & $(.010)$ & (.009) & $(.010)$ \\
\hline \multirow[t]{2}{*}{ In $\mathrm{Empl}_{f, t-1}$} & $-.699 * * *$ & $-.699 * * *$ & $-.699 * * *$ \\
\hline & $(.018)$ & (.018) & (.018) \\
\hline
\end{tabular}


T A B L E 7 (Continued)

\begin{tabular}{|c|c|c|c|}
\hline \multirow[b]{2}{*}{ Dep. var. } & \multicolumn{3}{|c|}{$\Delta \ln \operatorname{Empl}_{f, t}$} \\
\hline & (1) & (2) & (3) \\
\hline \multirow[t]{2}{*}{ Leverage $_{f, t-1}$} & .003 & .004 & .004 \\
\hline & $(.006)$ & $(.006)$ & $(.006)$ \\
\hline \multirow{2}{*}{$\mathrm{Age}_{f, t-1}$} & $.029 * * *$ & $.030 * * *$ & $.030^{* * *}$ \\
\hline & $(.003)$ & $(.003)$ & $(.003)$ \\
\hline Firm FE & Yes & Yes & Yes \\
\hline Year FE & Yes & Yes & Yes \\
\hline$N$ & $1,114,644$ & $1,114,644$ & $1,114,644$ \\
\hline $\operatorname{adj} . R^{2}$ & .329 & .329 & .329 \\
\hline
\end{tabular}

Note: Table reports the regressions for the determinants of firms' growth, $1998-2007 . \times D_{p, t-1}^{\% \text { Education }}$ and $\times D_{p, t-1}^{\% \text { Science }}$ are dummies taking value 1 if the share of public expenditures, for education and science respectively, over gross domestic product in province $p$ at time $t-1$ is above the average computed across all provinces at time $t-1$. Similarly, $\times D_{p, t-1}^{\% \text { Agglomeration }}$ is a dummy taking value 1 if the level of agglomeration in province $p$ is above the average. Results show the coefficients with standard errors (in parenthesis) clustered at the province-industry level: $* * *<.01 ; * *<.05$.

It is worth noticing that the two variables differ along various dimensions. Focusing on employment has the advantage to reduce measurement problems because it does not require to deflate the nominal series and it is not subject to the manipulation of reported sales and profits, which often occurs for tax-related purposes. Sales, moreover, may not be as coincident with production as is employment. On the other hand, the number of employees is the result not only of firm growth, but also of labor productivity and capital/labor substitution. Despite the substantial difference between the two series, we test the robustness of our results by replacing the dependent variable with the (logged difference of) sales of firm $f$ between period $t$ and $t$-1. Column (1) of Table 8 reports the results. As to what regional factors are concerned, all the estimated coefficients have the same sign as before, although some are not statistically significant. Notably, the coefficient of the provincial level of marketization preserves its positive sign, but is smaller. This suggests that firms located in areas making greater progress in establishing a market economy tend to grow both factor inputs (e.g., labor) and output (e.g., sales). Similar considerations hold for the agglomeration covariates and for the local government expenditures in education and science, in line with the recent findings offered by Zhu et al. (2019). These results confirm that during the reform period 1998-2007 the regional mechanisms fostering productivity gains in the incumbent firms (Ding, Guariglia, \& Harris, 2016) promoted also the growth of firm employment and sales. As to the firm-level variables, the estimates confirm previous findings. The coefficient for firm age for the growth of firm sales is negative, as found also by Zhu et al. (2019).

As far as the regional determinants are concerned, to facilitate the comparison with the baseline specification, in columns $2-5$ of Table 8 we modify one variable at the time starting from the proxy of specialization, that is replaced by using the value of production rather than that of sales (column 2). Human capital is proxied by the (log) local public expenditures in education and culture $\left(\operatorname{GovExpEdu}_{p, t-1}\right)$ in the province (column 3), innovation captures by the (log) local public expenditures in science and technology $\left(\right.$ GovExpScience $\left._{p, t-1}\right)$ (column 4), and the (log) number of pollution accidents stands for environmental protection (\#Pollution Accidents A,$t-1_{1}$ ) (column 5). The results are in line with those discussed before.

We further check the robustness of our main results by estimating the model on different sub-samples of firms (Table 9). The introduction of firm-level fixed effects in the estimation does not allow 

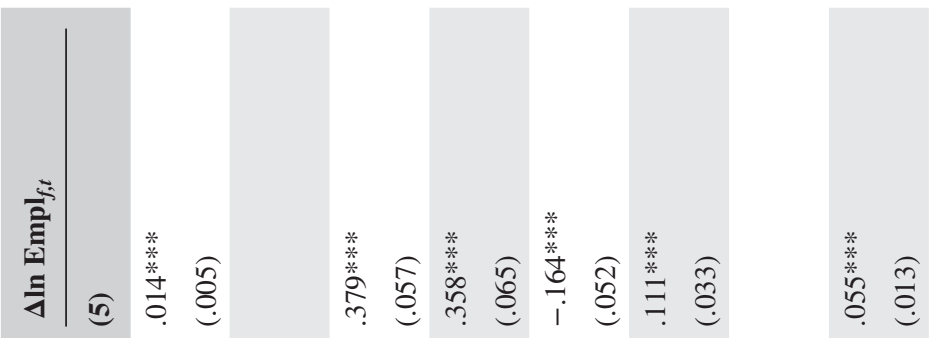

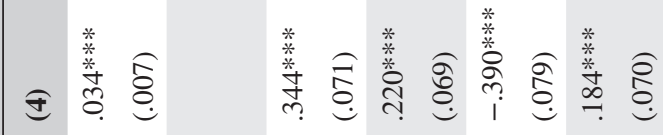

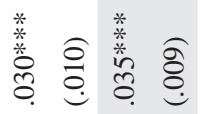
旁雪虽拿

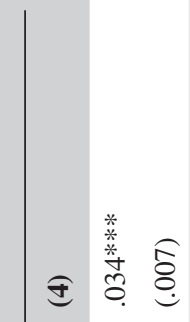

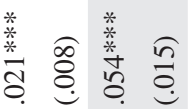

홍

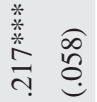

产

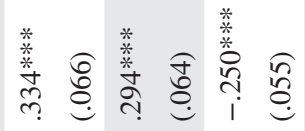

ส

$\frac{*}{*} \underset{*}{*} \stackrel{0}{*}$

ปั.

กิ กิ

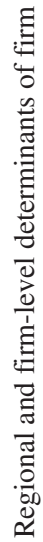

竎

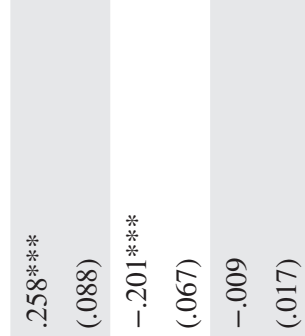

के ฮิ

\&.

\%

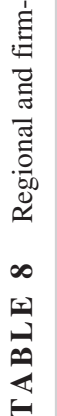

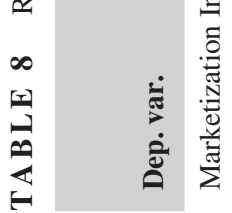
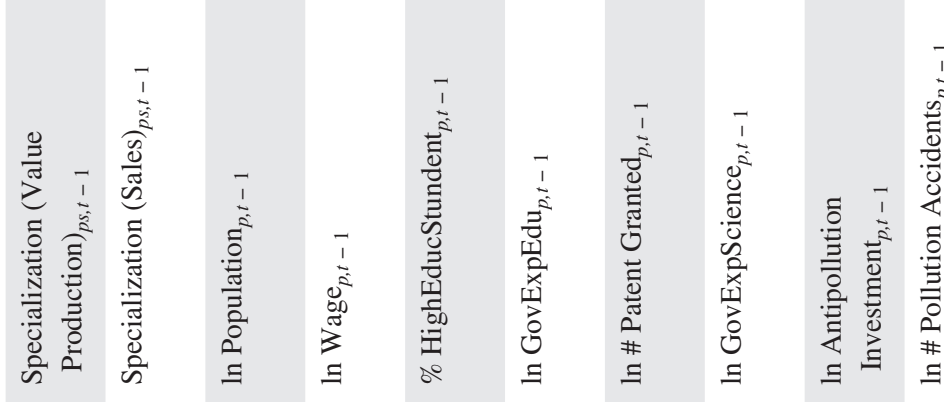


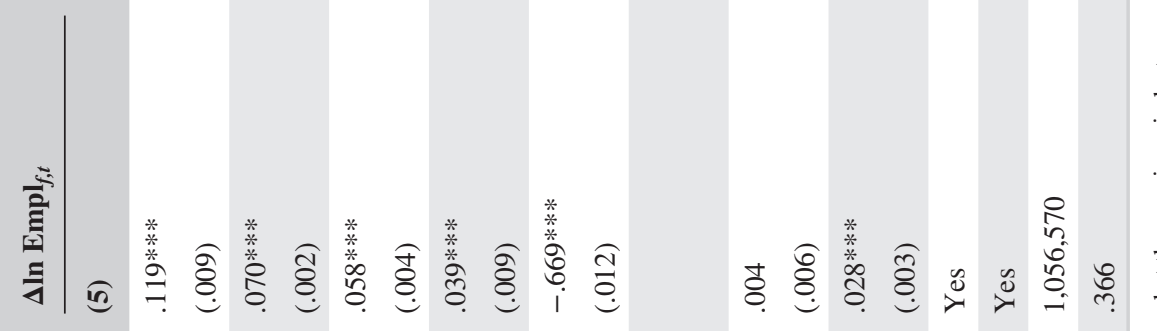

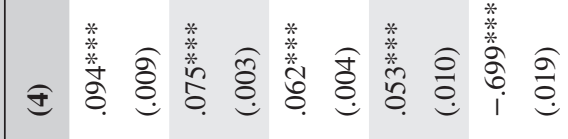

ڤ.

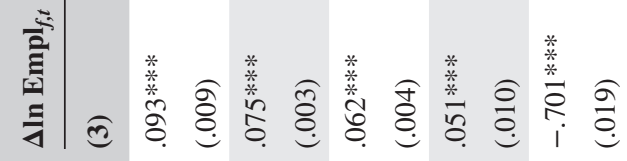
\&.

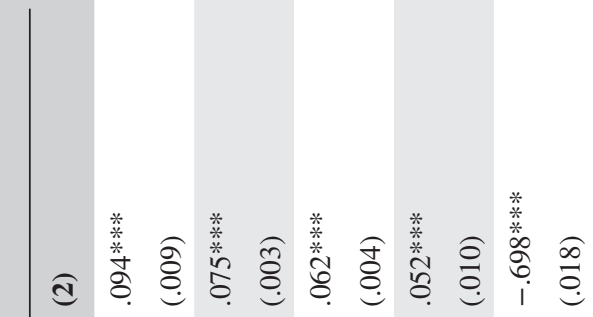

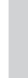


T A B LE 9 Regional and firm-level determinants of firm employment growth: different samples

\begin{tabular}{|c|c|c|c|c|c|}
\hline \multirow[b]{3}{*}{ Dep. var. } & \multicolumn{5}{|c|}{$\Delta \ln \operatorname{Empl}_{f, t}$} \\
\hline & \multirow{2}{*}{$\frac{\text { Small }}{(1)}$} & \multirow{2}{*}{$\frac{\text { Large }}{(2)}$} & \multirow{2}{*}{$\frac{\text { Low-Tech }}{(3)}$} & \multirow{2}{*}{$\begin{array}{l}\text { High-Tech } \\
(4)\end{array}$} & \multirow{2}{*}{$\begin{array}{l}\text { Balanced Panel } \\
(5)\end{array}$} \\
\hline & & & & & \\
\hline \multirow[t]{2}{*}{ Marketization Index ${ }_{p, t-1}$} & $.030 * * *$ & -.008 & $.023 * *$ & .019 & $.024 * * *$ \\
\hline & $(.009)$ & $(.005)$ & $(.011)$ & $(.012)$ & $(.007)$ \\
\hline \multirow{2}{*}{ Specialization $_{p s, t-1}$} & $.157 *$ & $.392 * *$ & $.459 * * *$ & $.258 * * *$ & $.279 * * *$ \\
\hline & $(.087)$ & $(.087)$ & $(.150)$ & $(.079)$ & $(.060)$ \\
\hline \multirow{2}{*}{ ln Population $_{p, t-1}$} & $.185^{* * *}$ & $.246 * * *$ & $.272 * * *$ & $.217 * *$ & $.257 * * *$ \\
\hline & $(.068)$ & $(.071)$ & $(.094)$ & $(.086)$ & $(.056)$ \\
\hline \multirow[t]{2}{*}{$\ln$ Wage $_{p, t-1}$} & $-.398 * * *$ & .016 & $-.415^{* * *}$ & $-.229 * *$ & $-.166^{* * *}$ \\
\hline & $(.084)$ & $(.050)$ & $(.105)$ & $(.108)$ & $(.062)$ \\
\hline \multirow[t]{2}{*}{$\%$ HighEducStundent $_{p, t-1}$} & $.182 * * *$ & -.017 & $.198 * *$ & .139 & $.136^{* *}$ \\
\hline & $(.070)$ & $(.015)$ & $(.095)$ & $(.092)$ & $(.056)$ \\
\hline \multirow{2}{*}{ ln \# Patent Granted ${ }_{p, t-1}$} & $.091 * * *$ & .013 & .031 & $.059 * * *$ & $.076 * * *$ \\
\hline & $(.015)$ & $(.015)$ & $(.022)$ & $(.022)$ & $(.015)$ \\
\hline \multirow{2}{*}{$\begin{array}{l}\text { In Antipollution } \\
\text { Investment }_{p, t-1}\end{array}$} & $.031 * * *$ & $.014 * * *$ & $.031 * * *$ & $.023 * *$ & $.025 * * *$ \\
\hline & $(.009)$ & $(.005)$ & $(.009)$ & $(.011)$ & $(.007)$ \\
\hline \multirow[t]{2}{*}{$\ln \mathrm{GDPpc}_{p, t-1}$} & $.316^{* * *}$ & .033 & $.326 * * *$ & $.229 * *$ & $.242 * * *$ \\
\hline & $(.083)$ & $(.040)$ & $(.103)$ & $(.095)$ & $(.057)$ \\
\hline \multirow[t]{2}{*}{$\%$ Private Firms $s_{p, t-1}$} & $.066 * * *$ & $.095 * * *$ & $.087 * * *$ & $.103 * * *$ & $.081 * * *$ \\
\hline & $(.010)$ & $(.007)$ & $(.013)$ & $(.012)$ & $(.008)$ \\
\hline \multirow[t]{2}{*}{$\ln \mathrm{TFP}_{f, t-1}$} & $.058 * * *$ & $.051 * * *$ & $.079 * * *$ & $.070 * * *$ & $.077 * * *$ \\
\hline & $(.003)$ & $(.003)$ & $(.004)$ & $(.005)$ & $(.003)$ \\
\hline \multirow{2}{*}{ Export Status $_{f, t-1}$} & $.044 * * *$ & $.036 * * *$ & $.057 * * *$ & $.066 * * *$ & $.065 * * *$ \\
\hline & $(.004)$ & $(.004)$ & $(.006)$ & $(.007)$ & $(.005)$ \\
\hline \multirow[t]{2}{*}{$\%$ NewProduct $_{f, t-1}$} & $.032 * * *$ & $.027 * * *$ & $.053 * * *$ & $.047 * * *$ & $.055 * * *$ \\
\hline & $(.010)$ & $(.010)$ & $(.015)$ & $(.013)$ & $(.010)$ \\
\hline \multirow[t]{2}{*}{$\ln \mathrm{Empl}_{f, t-1}$} & $-.803 * * *$ & $-.718 * * *$ & $-.729 * * *$ & $-.673 * * *$ & $-.546^{* * *}$ \\
\hline & $(.019)$ & $(.010)$ & $(.023)$ & $(.031)$ & $(.018)$ \\
\hline \multirow[t]{2}{*}{ Leverage $_{f, t-1}$} & .004 & -.012 & .003 & .005 & .000 \\
\hline & $(.006)$ & $(.008)$ & $(.008)$ & $(.009)$ & $(.007)$ \\
\hline \multirow[t]{2}{*}{$\operatorname{Age}_{f, t-1}$} & $.012 * * *$ & $.025 * * *$ & $.027 * * *$ & $.034 * * *$ & $.025 * * *$ \\
\hline & $(.004)$ & $(0.004)$ & $(.004)$ & $(.005)$ & $(.003)$ \\
\hline Firm FE & Yes & Yes & Yes & Yes & Yes \\
\hline Year FE & Yes & Yes & Yes & Yes & Yes \\
\hline$N$ & 879,956 & 234,688 & 673,861 & 440,642 & 376,106 \\
\hline adj. $R^{2}$ & .455 & .695 & .341 & .322 & .248 \\
\hline
\end{tabular}

Note: Table reports the regressions for the determinants of firms' growth, 1998-2007. Results show the coefficients with standard errors (in parenthesis) clustered at the province-industry level: $* * *<.01 ; * *<.05 ; *<.1$. 
to capture group-specific relationships between firm employment growth and its determinants. As group-related specificities might be present in our analysis, we take stock of previous studies addressing this possibility and, sample size permitting, we consider the sub-samples composed by, respectively, small versus. large, and low-tech versus high-tech firms. To identify small and large firms, we adopt the classification criteria employed by the Chinese authorities: small companies are defined as having less than 300 employees, small-medium firms are defined as employing less than 1,000 employees, and the remaining are treated as large. We characterize the technological orientation (either low or high technology) of an industry according to the OECD classification provided by Hatzichronoglou (1997), as done by Faggio, Silva, and Strange (2017).

Small and large enterprises, whose estimated parameters are reported, respectively, in columns (1) and (2) of Table 9, exhibit non-negligible differences among each other. The level of marketization has a positive impact on the employment growth of small companies, whereas its impact is not significant in the case of the large ones. This is consistent with the idea that the companies benefiting most of developed and well-functioning market-based mechanisms are the small (and often private) enterprises, whereas the employment decisions of the large (and often state owned or state controlled) ones are less or not affected by the level of marketization. On the contrary, large companies transform better agglomeration economies into higher employment growth. This is possibly due to the greater ability of large companies to gain from agglomeration and to bear its side effects. ${ }^{32}$ Furthermore, the results indicate that only the small companies increase their employment more if located in provinces in which investment in education, innovation, and environmental projects grow more. This is possibly due to the fact that large companies tend to tap more on internal knowledge, whereas smaller companies have to absorb externally created knowledge. As to the technology divide (columns 3 and 4), the estimations suggest that firm employment growth in low-tech companies is more strongly influenced by the regional determinants, with the only exception, somehow expected, regarding the role of local innovation investments. This is in line with previous evidence that low-tech companies in China exploit better the regional external economies to overcome internal limits and bottlenecks, but cannot make the best out of local innovation as they lack absorptive capacity.

As the entire sample used so far does not account for possible exit and entry, we want to avoid that our results are driven by the change in the composition of firms across provinces in the sample, due for instance to the massive entry of private enterprises replacing old established firms during the period under analysis. Thus, in column (5) of Table 9, we consider a balanced sample, whereby companies are retained only if they appear for at least nine consecutive years. All the results discussed above remain valid in both qualitative and quantitative terms, thereby strengthening our policy-relevant claim that the impact of the regional determinants on the growth of local employment occurs through the expansion of incumbent companies, and not only through firm dynamics as shown in other works reviewed in the introduction.

As the analysis employs, on the one hand, firm-level data on growth and, on the other hand, provincial data for the regional factors, it could be argued that the analysis suffers the lack of controls for the non-negligible differences across areas within provinces. ${ }^{33}$ To check the robustness of the results to the introduction of city-level variables capturing the local factors of interest, we reconstruct our local covariates at the city level, where possible. Two aspects are worth noticing: first, the marketization indices are not available at the sub-provincial level; second, data availability at this fine level of disaggregation imposes a small reduction in sample size. To compare these new results in Table 10 with those in Table 5, we run an estimation for both firm employment growth and sales growth. The results remain consistent with those discussed above. All the city-level regional factors keep the same sign as the provincial ones and are statistically significant; more importantly, the marketization index remains positively and statistically associated with firm employment growth. 
T A B LE 10 City and firm-level determinants of firm growth: multivariate

\begin{tabular}{|c|c|c|}
\hline \multirow[b]{2}{*}{ Dep. var. } & \multirow{2}{*}{$\frac{\Delta \ln \operatorname{Empl}_{f, t}}{(1)}$} & \multirow{2}{*}{$\frac{\Delta \ln \text { Sales }_{f, t}}{(2)}$} \\
\hline & & \\
\hline \multirow{2}{*}{ Marketization Index $\operatorname{x}_{p, t-1}$} & $.025 * * *$ & $.015^{* *}$ \\
\hline & $(.009)$ & $(.006)$ \\
\hline \multirow{2}{*}{ Specialization $_{c s, t-1}$} & $.166^{* * * *}$ & $.273 * * *$ \\
\hline & $(.050)$ & $(.049)$ \\
\hline \multirow{2}{*}{$\ln _{\text {Population }}{ }_{c p, t-1}$} & $.045 * * *$ & $.035^{*}$ \\
\hline & $(.011)$ & $(.020)$ \\
\hline \multirow[t]{2}{*}{$\ln$ Wage $_{c p, t-1}$} & $-.235^{* * *}$ & $-.118^{*}$ \\
\hline & $(.045)$ & (.069) \\
\hline \multirow{2}{*}{ In GovExpEdu ${ }_{c, t-1}$} & $.008 * *$ & $.018 * * *$ \\
\hline & $(.003)$ & $(.005)$ \\
\hline \multirow{2}{*}{ ln GovExpScience ${ }_{c, t-1}$} & $.008 * * *$ & $.009 * * *$ \\
\hline & $(.003)$ & $(.003)$ \\
\hline \multirow{2}{*}{ ln \# Patent Granted ${ }_{p, t-1}$} & $.078 * * *$ & .018 \\
\hline & $(.016)$ & $(.021)$ \\
\hline \multirow{2}{*}{ In Antipollution Investment ${ }_{p, t-1}$} & $.026 * * *$ & .007 \\
\hline & $(.008)$ & $(.005)$ \\
\hline \multirow[t]{2}{*}{$\ln \operatorname{GDPpc}_{c, t-1}$} & $.019 * *$ & $.047 * * *$ \\
\hline & (.009) & $(.010)$ \\
\hline \multirow{2}{*}{$\%$ Private Firms ${ }_{c, t-1}$} & $.088 * * *$ & $.088 * * *$ \\
\hline & $(.009)$ & $(.008)$ \\
\hline \multirow{2}{*}{$\ln \mathrm{TFP}_{f, t-1}$} & $.074 * * *$ & $.021 * * * *$ \\
\hline & $(.003)$ & $(.002)$ \\
\hline \multirow{2}{*}{ Export Status $_{f, t-1}$} & $.061 * * *$ & $.036 * * *$ \\
\hline & $(.004)$ & $(.006)$ \\
\hline \multirow[t]{2}{*}{$\%$ NewProduct $_{f, t-1}$} & $.053 * * *$ & $.056 * * *$ \\
\hline & $(.010)$ & $(.008)$ \\
\hline \multirow[t]{2}{*}{$\ln \operatorname{Empl}_{f, t-1}$} & $-.700 * * *$ & \\
\hline & $(.020)$ & \\
\hline \multirow{2}{*}{$\ln$ Sales $_{f, t-1}$} & & $-.498 * * *$ \\
\hline & & $(.007)$ \\
\hline \multirow{2}{*}{ Leverage $_{f, t-1}$} & .005 & .001 \\
\hline & $(.006)$ & $(.008)$ \\
\hline \multirow[t]{2}{*}{$\mathrm{Age}_{f, t-1}$} & $.030 * * *$ & $-.033 * * *$ \\
\hline & $(.003)$ & $(.004)$ \\
\hline Firm FE & Yes & Yes \\
\hline Year FE & Yes & Yes \\
\hline
\end{tabular}


TA B LE 10 (Continued)

\begin{tabular}{|c|c|c|}
\hline & $\Delta \ln \operatorname{Empl}_{f, t}$ & $\Delta \ln$ Sales $_{f, t}$ \\
\hline Dep. var. & (1) & (2) \\
\hline$N$ & $1,073,624$ & $1,072,483$ \\
\hline $\operatorname{adj} \cdot R^{2}$ & .329 & .350 \\
\hline
\end{tabular}

Note: Table reports the regressions for the determinants of firms' growth, 1998-2007. Columns 1 and 2 show that results using Employment and Sales, respectively. Variable at city level are indexed by $c$, those at provincial level by $p$. Results show the coefficients with standard errors (in parenthesis) clustered at the province-industry level: $* * *<.01 ; * *<.05 ; *<.1$.

\section{5 | CLOSING REMARKS}

Heterogeneity is a well acknowledged feature in the literature focusing on firm growth. Several studies have shown that the observed diversity in firm employment growth can be linked to the variation in firm-level characteristics and in the resources embedded within the companies. Yet, little is known about the impact of framing conditions and regional characteristics, despite the recognized importance that institutions, agglomeration externalities, human capital endowment and forces of innovation have for the growth in aggregate production, productivity and employment.

Given the large variation in firm growth across the Chinese provinces and considering the profound changes occurred in China during the transition towards a market economy, China represents an ideal "laboratory" to deepen the understanding of the effects that local determinants have on firms' growth performance. Several scholars have provided evidence that regional economic and institutional factors contributed to shape the aggregate performances of Chinese provinces by means of their effects on enterpreneurship and industry dynamics. No evidence has, however, been offered on whether these features, and in particular the level of marketization, also impacted on the size of the employment of incumbent firms, another important channel of aggregate employment dynamics.

Drawing on a large firm-level data set merged with data on region-specific characteristics, we examine Chinese firm employment growth and its determinants over the period of 1998-2007. To summarize our main results, we show that firm employment growth is systematically affected by the business environment and institutional context where the firm is located, in addition to being influenced by firm-specific features and strategies. More specifically, firm employment in China appears to have grown faster in those firms that were located in provinces converging more rapidly towards a market economy (in particular in terms of improved government-market relationships) and exhibiting relatively better patterns in terms of agglomeration, endowment of human capital, innovation, and environmental protection. By studying firm employment growth of incumbent firms, this paper complements previous works (reviewed in the introduction) on entrepreneurship and industry dynamics, and shows the importance of regional economic and institutional factors in shaping aggregate employment performances through the impact on the incumbent firms. All the findings remain robust to the inclusion of a set of firm-level variables identified in the literature as critical internal features of firm growth (i.e., size, productivity, innovation, export and financial conditions), as well as to the adoption of various sets of fixed effects, alternative operationalizations of the regional variables of interest, subsamples of firms, and controls for regional factors at a finer level of aggregation.

This work provides new evidence on the fact that differences across regions are crucial determinants of firms' performance and growth (as suggested by Barbosa \& Eiriz, 2011; Ipinnaiye, Dineen, et al., 2017; Ipinnaiye, Lenihan, et al., 2017, for other countries), and particularly so in countries, such as China, experiencing structural changes and moving towards a market economy. Indeed, the Chinese 
regions where the institutional and economic environments are more advanced appear also characterized by firms whose employment grows faster, even controlling for the individual firms differences.

From a policy perspective, these findings imply that reforms and policy interventions designed to enhance regional investment and improve the degree of marketization tend to produce higher employment growth in the incumbent firms, besides fostering greater economic dynamism. Thus, if employment growth is a policy goal, regions that lag behind in terms of employment opportunities should devote resources to improve the institutional environment and invest in knowledge-related assets, besides implementing ad hoc measures to support specific industries and firms. The quality of government-market relationship appears the most influential component of the marketization process, more than the extent of privatization. This does not imply that only reforms directed to improve the government-market relationship should be focused upon: as our results show that there exist local mediating factors and that different dimensions of local development reinforce each other, our findings provide evidence on the importance of an harmonious and far reaching process of transformation, characterized by non-market-distorting policy interventions and public investment in human capital, environment and science. In sum, these results inform Chinese policy makers as they show that in order to achieve higher firm employment growth, it is necessary to accompany fiscal stimuli with reforms accelerating the transition towards a market economy and policies improving various aspects of the local environment. The regionally decentralized institutional system in China should facilitate the success of such place-based policy measures and of progressive institutional reforms tailored by the local Chinese authorities to meet the needs of the specific regions.

\section{ORCID}

\section{Andrea Fracasso (iD https://orcid.org/0000-0003-1581-8481}

\section{ENDNOTES}

${ }^{1}$ See Sutton (1997) and Coad (2009) for early reviews.

${ }^{2}$ There might be two reasons for the shortage of empirical analyses on this. One is the particular relevance of the issue for countries in transition (Zhu et al., 2019), for which good quality firm-level data are not often available. Another one is the simplistic juxtaposition of the determinants of employment growth and those of productivity growth (covered by a rich strand of literature), a treatment that implies assuming that regional factors (such as institutions and agglomeration economies) affect equally production, productivity and employment.

${ }^{3}$ China's transition process since 1978 is marked by a series of gradual and incremental reforms. See Zhang and Zou (2012) and Zhou $(2011,2014)$ for a detailed discussion of the major political events and economic reforms that have been implemented in China throughout the transition to a full-fledged market economy.

${ }^{4}$ Duschl et al. (2015) explore the industry-specific role of agglomeration economies on firm growth, thereby combining local factors with an industry-specific focus as done by Mazzucato and Parris (2015), who assess the importance of an industry-specific element (i.e., the industry's life cycle) for the R\&D-growth relationship at the firm level.

${ }^{5}$ Similar results are confirmed once the analysis is extended to the period 1997-2014, as done by Fan et al. (2018).

${ }^{6} \mathrm{~A}$ limited number of studies have also looked at the impact of local institutions on firms' productivity or profitability (see, among others, Lu et al., 2013; Lu \& Tao, 2009; Du et al., 2012; Zhou, 2014; Zhu et al., 2019).

${ }^{7}$ Prior research has also emphasized the role that informal institutional arrangements have on entrepreneurial development in transition economies, including China. See, for instance, Peng (2004) and Tan et al. (2009).

${ }^{8}$ Focusing on the reform of the governance of state-owned enterprises, many studies (see Shi \& Sun, 2016; Wei \& Tang, 2019, among others) consider the ownership transformation and its effects on Chinese firm-level performances (i.e., downsizing of employment, increased labour productivity and rising profitability). These works suggest that the extent to which market-oriented reforms were applied at the local level did have an impact, together with other local determinants, on individual Chinese firms' performances and, through these latter, on regional dynamics. 
${ }^{9}$ The literature on market-oriented reforms is rich and complex. See Rodrik (1996) and Sachs and Warner (1995) for essays on basic concepts and meanings of reforms.

${ }^{10}$ The idea that context-related conditions are fundamental drivers of local growth has been extensively considered by the macroeconomic and the regional literature. Contributions in these strands have mainly focused on aggregated data either at the national or at the regional level, whereas we consider here exclusively firm employment growth.

${ }^{11}$ Notably, as explained by Beaudry and Schiffauerova (2009), the great majority of works have focused either on firm productivity (Cainelli et al., 2015; Martin et al., 2011; van Oort et al., 2012) or on the survival rate of entrepreneurial firms (Tavassoli \& Jienwatcharamongkhol, 2016).

${ }^{12} \mathrm{As}$ far as the antipollution investments are concerned, air quality in China is notoriously poor and has recently become an issue associated with increasing social unrest. While our focus here is on the implications in terms of firms' growth and performance, others studies have dealt with the negative effects of pollution in terms of health and life expectancy (Chen et al., 2013).

${ }^{13}$ This data set has already been explored by a number of authors, such as Bin et al. (2018); Brandt et al. (2012); Ding et al. (2016); Guariglia et al. (2011); Manova and Yu (2016); Rizov and Zhang (2014); Yu (2015).

${ }^{14}$ The data set contains values for 30 of the 31 Chinese provinces and municipalities. Tibet is removed because of missing data.

${ }^{15}$ This index has been recently updated by Fan et al. (2017) for a longer period ranging from 1997 to 2014.

${ }^{16}$ While the size of government per se is not a yardstick to assess the distance from a market economy, it appears an appropriate measure in China during the period under observation: at this stage of the transition, China was still a developmental state and a reduction of the size of the local and central government was inevitable.

${ }^{17}$ Among the indicators, the index includes the share of rural workers in total urban employment, the share of banking deposits in non-state financial institutions, the share of bank loans to non-state enterprises, the market value of technological achievements per capita technical personnel, the ratio of foreign direct investment over GDP.

${ }^{18}$ Four indicators are used: the share of independent accountants and lawyers in total population, the entrepreneurs' evaluation of the legal environment for businesses, the number of patent applications and of grants per technical personnel.

${ }^{19}$ We would like to thank an anonymous reviewer for pointing this out.

${ }^{20}$ Notably, using a variable exploiting production instead of sales has no impact on the results.

${ }^{21}$ Prodi et al. (2018) employ granted patents to analyse volume and quality of innovative activities and their uneven distribution at a local level in China.

${ }^{22}$ Clearly, the number of pollution accidents may depend on both the attention paid to safety and to the intensity of the activities. These latter are controlled for in the regression by other covariates.

${ }^{23}$ Several works emphasize the high contribution of private enterprises to China's growth miracle over the past decades (Li et al., 2012). See, in particular, Schweinberger (2014) on State capitalism and private entrepreneurship in China.

${ }^{24}$ While other estimation methods are available, Olley and Pakes (1996) is the most popular approach among the empirical works focusing on firm-level data in China. This is possibly due to the dismal results (i.e., negative estimated coefficients) obtained after applying the approach developed by Levinsohn and Petrin (2003) and its recent reformulation by Wooldridge (2009), as found by Ding et al. (2016).

${ }^{25}$ It could be argued that, to the extent that more productive firms tend to minimise inputs per unit of output, firms shedding (hiring) workers fast may improve (lower) the productivity, with a reverse direction of causality. Although possible in theory, this issue does not affect our estimations as the productivity level, not its change, is encompassed in the specification with employment growth. Besides ruling out reverse causality, our specification reduces also other endogeneity problems thanks to the presence of firm fixed effects, the time lag of productivity, and the large number of (lagged) firm-level covariates included.

${ }^{26}$ It is worth noticing that the expected relationship between firm leverage and firm growth is not obvious at the theoretical level. On the one hand, leverage may be positively associated with growth if firms must resort to external financing to expand their capacity, but, on the other hand, there might be a negative relationship if fast-growing enterprises generate internal cash flows large enough to expand production without modifying the leverage. As companies can 
modify their leverage via financial operations that are not associated with changes in production, however, it is equally possible that the two variables are not correlated.

${ }^{27}$ All these are conservative choices. Zhu et al. (2019), for instance, explore the covariates of firm sales growth using neither firm-level fixed effects, nor instrumental variable, as the use of lagged covariates and the level of aggregation of regional factors are said to suffice for ruling out endogeneity issues.

${ }^{28}$ It is worth noting that this is not a dynamic specification as it does not contain the lagged value of the dependent variable. Accordingly, we can introduce in the specification both firm-level fixed effects to account for unobserved time-invariant heterogeneity and the lagged value of employment in level, as done in other works adopting this approach.

${ }^{29}$ Admittedly, the productivity of the firm could be affected by some of the regional determinants as well, as suggested by previous works. While this might be the case, the fixed-effect specification and the use of a lagged value of firm productivity reduce the relevance of the issue; more importantly, this would not determine any endogeneity problems for the regional factors that we aim to investigate. Rather, it would suggest that the estimated parameters for the regional covariates are to be interpreted as direct effects, net of any indirect influence they might have through other firm-level effects. We would thank an anonymous reviewer for leading us to clarify the issue.

${ }^{30}$ Liu et al. (2018) use the contemporaneous value and its first lag as instrument: we err on the safe side by considering a further lag for both.

${ }^{31}$ This is not entirely surprising as the privatization of large state-owned companies in the late 1990s was associated with labour shedding, only partly absorbed by the fast-growing employment in private firms.

${ }^{32}$ This result is at odds with van Oort et al. (2012) who find that smaller Dutch firms benefit more than the large ones from agglomeration economies. One should however keep in mind that the Chinese dataset does not contain very small companies, that are instead in the sample of Dutch companies investigated by van Oort et al. (2012). This might be relevant given the highly non-linear effects they find in their work.

${ }^{33} \mathrm{We}$ would like to thank an anonymous reviewer for having suggested this extension.

\section{REFERENCES}

Acemoglu, D., \& Robinson, J. (2010). The role of institutions in growth and development. Review of Economics and Institutions, 1 .

Aron, J. (2000). Growth and institutions: A review of the evidence. The World Bank Research Observer, 15, 99-135.

Audretsch, D., \& Dohse, D. (2007). Location: A neglected determinant of firm growth. Review of World Economics (Weltwirtschaftliches Archiv), 143, 79-107.

Audretsch, D. B. (1995). Innovation and industry evolution. Cambridge, MA: MIT Press.

Babecky, J., \& Campos, N. F. (2011). Does reform work? An econometric survey of the reform-growth puzzle. Journal of Comparative Economics, 39, 140-158.

Bai, C.-E., Lu, J., \& Tao, Z. (2006). The multitask theory of state enterprise reform: Empirical evidence from China. The American Economic Review, 96, 353-357.

Barbosa, N., \& Eiriz, V. (2011). Regional variation of firm size and growth: The Portuguese case. Growth and Change, $42,125-158$.

Beaudry, C., \& Schiffauerova, A. (2009). Who's right, Marshall or Jacobs? The localization versus urbanization debate. Research Policy, 38, 318-337.

Beck, T., Demirguc-Kunt, A., \& Vojislav, M. (2005). Financial and legal constraints to growth: Does firm size matter? The Journal of Finance, 60, 137-177.

Bin, P., Chen, X., Fracasso, A., \& Tomasi, C. (2018). Resource allocation and productivity across provinces in China. International Review of Economics and Finance, 57, 103-113.

Bogliacino, F., \& Pianta, M. (2010). Innovation and employment: A reinvestigation using revised pavitt classes. Research Policy, 39, 799-809.

Bojas, P., \& Barbosa, N. (2015). High-growth firms: What is the impact of region-specific characteristics? In R. Baptista \& J. Leitão (Eds.), Entrepreneurship, human capital, and regional development: labor networks (pp. 295-308). Basel, Switzerland: Springer.

Bottazzi, G., Secchi, A., \& Tamagni, F. (2008). Productivity, profitability and financial performance. Industrial and Corporate Change, 17, 711-751. 
Bottazzi, G., Secchi, A., \& Tamagni, F. (2014). Financial constraints and firm dynamics. Small Business Economics, 42, 99-116.

Brandt, L., Van Biesebroeck, J., \& Zhang, Y. (2012). Creative accounting or creative destruction? Firm-level productivity growth in Chinese manufacturing. Journal of Development Economics, 97, 339-351.

Brandt, L., Van Biesebroeck, J., \& Zhang, Y. (2014). Challenges of working with the Chinese NBS firm-level data. China Economic Review, 30, 339-352.

Bravo-Biosca, A., Criscuolo, C., \& Menon, C. (2016). What drives the dynamics of business growth? Economic Policy, 31, 703-742.

Cainelli, G., Fracasso, A., \& Vittucci Marzetti, G. (2015). Spatial agglomeration and productivity in Italy: A panel smooth transition regression approach. Papers in Regional Science, 94, 39-67.

Cassia, L., Colombelli, A., \& Paleari, S. (2009). Firms' growth: Does the innovation system matter? Structural Change and Economic Dynamics, 20, 211-220.

Cecere, G., \& Mazzanti, M. (2017). Green jobs and eco-innovations in European SMEs. Resource and Energy Economics, 49, 86-98.

Che, Y., Lu, Y., \& Tao, Z. (2017). Institutional quality and new firm survival. Economics of Transition and Institutional Change, 25, 495-525.

Chen, Y., Greenstone, A. E. M., \& Li, H. (2013). Evidence on the impact of sustained exposure to air pollution on life expectancy from China's Huai River policy. Proceedings of National Academy of Science United States of America, 110, 12936-12941.

Cintio, M. D., Ghosh, S., \& Grassi, E. (2017). Firm growth, R\&D expenditures and exports: An empirical analysis of Italian SMEs. Research Policy, 46, 836-852.

Coad, A. (2007). Testing the principle of "growth of the fitter": The relationship between profits and firm growth. Structural Change and Economic Dynamics, 18, 370-386.

Coad, A. (2009). The growth of firms: A survey of theories and empirical evidence. Cheltenham: Edward Elgar Publishing.

Coad, A. (2010). Neoclassical vs evolutionary theories of financial constraints: Critique and prospectus. Structural Change and Economic Dynamics, 21, 206-218.

Coad, A., \& Holzl, W. (2012).Firm growth: Empirical analysis, ch. 24. In M. Dietrich \& J. Krafft (Eds.), Handbook on the economics and theory of the firm. Cheltenham: Edward Elgar Publishing.

Coad, A., Segarra, A., \& Teruel, M. (2016). Innovation and firm growth: Does firm age play a role? Research Policy, 45, 387-400.

Cucculelli, M., \& Ermini, B. (2012). New product introduction and product tenure: What effects on firm growth? Research Policy, 41, 808-821.

Cull, R., \& Xu, L. C. (2005). Institutions, ownership, and finance: The determinants of profit reinvestment among Chinese firms. Journal of Financial Economics, 77, 117-146.

Dachs, B., \& Peters, B. (2014). Innovation, employment growth, and foreign ownership of firms. Research Policy, 43, 214-232.

Davidsson, P. (1991). Continued entrepreneurship: Ability, need, and opportunity as determinants of small firm growth. Journal of Business Venturing, 6, 405-429.

Dawson, J. W. (1998). Institutions, investment, and growth: New cross-country and panel data evidence. Economic Inquiry, 36, 603-619.

de Melo, M., Denizer, C., Gelb, A., \& Tenev, S. (2001). Circumstance and choice: The role of initial conditions and policies in transition economies. The World Bank Economic Review, 15, 1-31.

Degryse, H., Lu, L., \& Ongena, S. (2016). Informal or formal financing? Evidence on the co-funding of Chinese firms. Journal of Financial Intermediation, 27, 31-50.

Delmar, F. (1997). Measuring growth: Methodological considerations and empirical results. In R. Donckels \& A. Miettinen (Eds.), Entrepreneurship and SME research: On its way to the next millennium (pp. 190-216). Aldershot, VA: Avebury.

Ding, S., Guariglia, A., \& Harris, R. (2016). The determinants of productivity in Chinese large and medium-sized industrial firms, 1998-2007. Journal of Productivity Analysis, 45, 131-155.

Dosi, G. (2008). Statistical regularities in the evolution of industries. A guide through some evidence and challenges for the theory. L'industria, 2(2008), 185-220. 
Dosi, G., \& Nelson, R. R. (2010).Technical change and industrial dynamics as evolutionary processes.In B. H. Hall \& N. Rosenberg (Eds.), Handbook of the economics of innovation (Vol. 1, pp. 51-127). Amsterdam: North Holland Publishing Company.

Dosi, G., \& Yu, X. (2019). Technological catching-up, sales dynamics, and employment growth: Evidence from Chinas manufacturing. Industrial and Corporate Change, 28(1), 79-107.

Du, J., Lu, Y., \& Tao, Z. (2012). Contracting institutions and vertical integration: Evidence from Chinas manufacturing firms. Journal of Comparative Economics, 40, 89-107.

Duranton, G., \& Puga, D. (2004).Micro-foundations of urban agglomeration economies, chap. 48.In J. V. Henderson \& J. F. Thisse (Eds.), Handbook of regional and urban economics (Vol. 4, pp. 2063-2117). Amsterdam: Elsevier.

Duschl, M., Scholl, T., Brenner, T., Luxen, D., \& Raschke, F. (2015). Industry-specific firm growth and agglomeration. Regional Studies, 49, 1822-1839.

Easterly, W., \& Levine, R. (2003). Tropics, germs, and crops: How endowments influence economic development. Journal of Monetary Economics, 50, 3-39.

Faggio, G., Silva, O., \& Strange, W. C. (2017). Heterogeneous agglomeration. The Review of Economics and Statistics, 99, 80-94.

Fagiolo, G., \& Luzzi, A. (2006). Do liquidity constraints matter in explaining firm size and growth? Some evidence from the Italian manufacturing industry. Industrial and Corporate Change, 15, 1-39.

Falcetti, E., Raiser, M., \& Sanfey, P. (2002). Defying the odds: Initial conditions, reforms, and growth in the first decade of transition. Journal of Comparative Economics, 30, 229-250.

Fan, G., Guarong, M., \& Xiaolu, W. (2018). Marketisation in China from 1997 to 2014: Achievements and contribution to growth. In R. Garnaut, L. Song, \& C. Fang (Eds.), Chinas 40 years of reform and development: 1978-2018. Acton, ACT: ANU Press.

Fan, G., Xiaolu, W., \& Guarong, M. (2011). Contribution of marketization to China's economic growth. Economic Research Journal, 9, 4-16.

Fan, G., Xiaolu, W., \& Zhu, H. (2007). NERI index of marketization of Chinas provinces: 2006 report (Tech. Rep.). Beijing: Social Sciences Academic Press.

Fan, G., Xiaolu, W., \& Zhu, H. (2017). NERI index of marketization of Chinas provinces: 2016 report (Tech. Rep.). Beijing: Social Sciences Academic Press.

Fracasso, A., \& Vittucci Marzetti, G.(2018). Estimating dynamic localization economies: The inadvertent success of the specialization index and the location quotient. Regional Studies, 52, 119-132.

Gabe, T. M., \& Kraybill, D. S. (2002). The effect of state economic development incentives on employment growth of establishments. Journal of Regional Science, 42, 703-730.

Ganau, R., \& Rodriguez-Pose, A. (2019). Do high-quality local institutions shape labour productivity in Western European manufacturing firms? Papers in Regional Science, 98, 1633-1666.

Geenhuizen, M., \& Reyes-Gonzalez, L. (2007). Does a clustered location matter for hightechnology companies' performance? The case of biotechnology in the Netherlands. Technological Forecasting and Social Change, 74, 1681-1696.

Gilbert, B. A., McDougall, P. P., \& Audretsch, D. B. (2008). Clusters, knowledge spillovers and new venture performance: An empirical examination. Journal of Business Venturing, 23, 405-422.

Guariglia, A., Liu, X., \& Song, L. (2011). Internal finance and growth: Microeconometric evidence on Chinese firms. Journal of Development Economics, 96, 79-94.

Guo, Q., He, C., \& Li, D. (2016). Entrepreneurship in China: The role of localisation and urbanisation economies. Urban Studies, 53, 2584-2606.

Gwartney, J. D., Holcombe, R. G., \& Lawson, R. A. (2004). Economic freedom, institutional quality, and cross-country differences in income and growth. Cato Journal, 24, 205-233.

Hall, B. H., Lotti, F., \& Mairesse, J. (2008). Employment, innovation, and productivity: Evidence from Italian microdata. Industrial and Corporate Change, 17, 813-839.

Hall, B. H., Lotti, F., \& Mairesse, J. (2009). Innovation and productivity in SMEs: Empirical evidence for Italy. Small Business Economics, 33, 13-33.

Harrison, R., Jaumandreu, J., Mairesse, J., \& Peters, B. (2014). Does innovation stimulate employment? A firmlevel analysis using comparable micro-data from four European countries. International Journal of Industrial Organization, 35, 29-43. 
Hasan, I., Kobeissi, N., Wang, H., \& Zhou, M. (2015). Banking structure, marketization, and small business development: Regional evidence from China. Pacific Economic Review, 20, 487-510.

Hatzichronoglou, T. (1997). Revision of the high-technology sector and product classification. OECD Science, Technology and Industry Working Papers No. 1997/02. Paris: OECD Publishing.

He, C., Wei, Y. D., \& Xie, X. (2008). Globalization, institutional change, and industrial location: Economic transition and industrial concentration in China. Regional Studies, 42, 923-945.

He, C., Yan, Y., \& Rigby, D. (2018). Regional industrial evolution in China. Papers in Regional Science, 97, $173-198$.

He, C., \& Yang, R. (2016). Determinants of firm failure: Empirical evidence from China. Growth and Change, 47, 72-92.

Horbach, J., \& Janser, M. (2016). The role of innovation and agglomeration for employment growth in the environmental sector. Industry and Innovation, 23, 488-511.

Ipinnaiye, O., Dineen, D., \& Lenihan, H. (2017). Drivers of SME performance: A holistic and multivariate approach. Small Business Economics, 48, 883-911.

Ipinnaiye, O., Lenihan, H., \& Doran, J. (2017). Firm growth and regional factors: Evidence from Ireland. Conference Paper at Regional Studies Association International Conference, Trinity College, Dublin.

Ketterer, T. D., \& Rodrguez-Pose, A. (2018). Institutions vs. first-nature geography: What drives economic growth in Europe's regions? Papers in Regional Science, 97, S25-S62.

Kim, S., \& Law, M. T. (2012). History, institutions, and cities: A view from the Americas. Journal of Regional Science, $52,10-39$.

Kunapatarawong, R., \& Martinez-Ros, E. (2016). Towards green growth: How does green innovation affect employment? Research Policy, 45, 1218-1232.

Lachenmaier, S., \& Rottmann, H. (2011). Effects of innovation on employment: A dynamic panel analysis. International Journal of Industrial Organization, 29, 210-220.

Lai, Y., \& Vonortas, N. S. (2019). Regional entrepreneurial ecosystems in China. Industrial and Corporate Change, $28,875-897$.

Lasagni, A., Nifo, A., \& Vecchione, G. (2015). Firm productivity and Institutional quality: Evidence from Italian industry. Journal of Regional Science, 55, 774-800.

Leoncini, R., Marzucchi, A., Montresor, S., Rentocchini, F., \& Rizzo, U. (2019). Better late than never': The interplay between green technology and age for firm growth. Small Business Economics., 52(4), 891-904.

Levinsohn, J., \& Petrin, A. (2003). Estimating production functions using inputs to control for unobservables. Review of Economic Studies, 70, 317-341.

Li, H., Yang, Z., Yao, X., Zhang, H., \& Zhang, J. (2012). Entrepreneurship, private economy and growth: Evidence from China. China Economic Review, 23, 948-961.

Liu, C. Y., \& Huang, X. (2016). The rise of urban entrepreneurs in China: Capital endowments and entry dynamics. Growth and Change, 47, 32-52.

Liu, J., Tang, J., Zhou, B., \& Liang, Z. (2018). The effect of governance quality on economic growth: Based on Chinas provincial panel data. Economies, 6(4), 1-23.

Lu, J., \& Tao, Z. (2010). Determinants of entrepreneurial activities in China. Journal of Business Venturing, 25, $261-273$.

Lu, Y., Png, I. P., \& Tao, Z. (2013). Do institutions not matter in China? Evidence from manufacturing enterprises. Journal of Comparative Economics, 41, 74-90.

Lu, Y., \& Tao, Z. (2009). Contract enforcement and family control of business: Evidence from China. Journal of Comparative Economics, 37, 597-609.

Manova, K., \& Yu, Z. (2016). How firms export: Processing vs. ordinary trade with financial frictions. Journal of International Economics, 100, 120-137.

Martin, P., Mayer, T., \& Mayneris, F. (2011). Spatial concentration and plant-level productivity in France. Journal of Urban Economics, 69, 182-195.

Mazzucato, M., \& Paris, S. (2015). High-growth firms in changing competitive environments: the US pharmaceutical industry (1963 to 2002). Small Business Economics, 44, 145-170.

Melo, P. C., Graham, D. J., \& Noland, R. B. (2009). A meta-analysis of estimates of urban agglomeration economies. Regional Science and Urban Economics, 39, 332-342.

Meyer, K. E., \& Nguyen, H. V. (2005). Foreign investment strategies and sub-national institutions in emerging markets: Evidence from Vietnam. Journal of Management Studies, 42, 63-93. 
Milln, J. M., Congregado, E., Romn, C., van Praag, M., \& van Stel, A. (2014). The value of an educated population for an individual's entrepreneurship success. Journal of Business Venturing, 29, 612-632.

Moretti, E. (2004a). Human capital externalities in cities, chap. 51.In J. V. Henderson \& J. F. Thisse (Eds.), Handbook of regional and urban economics (Vol. 1, pp. 2243-2291). Amsterdam: Elsevier.

Moretti, E. (2004b). Workers' education, spillovers, and productivity: Evidence from plant-level production functions. American Economic Review, 94, 656-690.

Moschella, D., Tamagni, F., \& Yu, X. (2019). Persistent high-growth firms in China's manufacturing. Small Business Economics, 52, 573-594.

Nakagane, K., \& Mitsunami, K. (2018). Nexus between privatization and marketization during transition process: An experimental analysis based on Chinas provincial panel data. Journal of Contemporary East Asia Studies, 7, 50-75.

Nguyen, T. V., Le, N. T., \& Bryant, S. E. (2013). Sub-national institutions, firm strategies, and firm performance: A multilevel study of private manufacturing firms in Vietnam. Journal of World Business, 48, 68-76.

North, D. C. (1991). Institutions. Journal of Economic Perspectives, 5, 97-112.

Olley, G. S., \& Pakes, A. (1996). The dynamics of productivity in the telecommunications equipment industry. Econometrica, 64, 1263-1297.

Pan, F., \& Yang, B. (2019). Financial development and the geographies of startup cities: Evidence from China. Small Business Economics, 52, 743-758.

Peng, Y. (2004). Kinship networks and entrepreneurs in China's transitional economy. American Journal of Sociology, 109, 1045-1074.

Peric, M., \& Vitezic, V. (2016). Impact of global economic crisis on firm growth. Small Business Economics, 46, 1-12.

Poncet, S., Steingress, W., \& Vandenbussche, H. (2010). Financial constraints in China: Firm-level evidence. China Economic Review, 21, 411-422.

Prodi, G., Frattini, F., \& Nicolli, F. (2018). The diffusion and embeddedness of innovative activities in China. Economia Politica., 35(1), 71-106.

Qian, H. (2010). Talent, creativity and regional economic performance: The case of China. The Annals of Regional Science, 45, 133-156.

Rizov, M., \& Zhang, X. (2014). Regional disparities and productivity in China: Evidence from manufacturing micro data. Papers in Regional Science, 93, 321-339.

Rodrik, D. (1996). Understanding economic policy reform. Journal of Economic Literature, 34, 9-41.

Roland, G. (2000). Transition and economics: Politics, markets, and firms. Chicago: The MIT Press.

Rosenthal, S. S., \& Strange, W. C. (2004). Evidence on the nature and sources of agglomeration economies, chap. 49. In J. V. Henderson \& J. F. Thisse (Eds.), Handbook of regional and urban economics (Vol. 4, pp. 2119-2171). Amsterdam: Elsevier.

Sachs, J. D., \& Warner, A. (1995). Economic reform and the process of global integration. Brookings Papers on Economic Activity, 26, 1-118.

Schweinberger, A. (2014). State capitalism, entrepreneurship, and networks: China's rise to a superpower. Journal of Economic Issues, 48, 169-180.

Shi, W., \& Sun, J. (2016). The impact of privatization on efficiency and profitability. Economics of Transition and Institutional Change, 24, 393-420.

Smallbone, D., \& Welter, F. (2012). Entrepreneurship and institutional change in transition economies: The commonwealth of independent states, central and eastern Europe and China compared. Entrepreneurship \& Regional Development, 24, 215-233.

Song, L., \& Winkler, C. (2014). China's trans-regional entrepreneurship: A panel data analysis of 31 provinces. Journal of Entrepreneurship in Emerging Economies, 6, 202-222.

Sousa, N., Rueda-Cantuche, J. M., Arto, I., \& Andreoni, V. (2012). Extra EU exports and employment. DG TRADE Chief Economist Notes 2012-2, Directorate General for Trade, European Commission.

Sutton, J. (1997). Gibrat's legacy. Journal of Economic Literature, 35, 40-59.

Tan, J., Yang, J., \& Veliyath, R. (2009). Particularistic and system trust among small and medium enterprises: A comparative study in China's transition economy. Journal of Business Venturing, 24, 544-557.

Tavassoli, S., \& Jienwatcharamongkhol, V. (2016). Survival of entrepreneurial firms: The role of agglomeration externalities. Entrepreneurship \& Regional Development, 28, 746-767.

van Oort, F. G., Burger, M. J., Knoben, J., \& Raspe, O. (2012). Multilevel approaches and the firm-agglomeration ambiguity in economic growth. Journal of Economic Surveys, 26, 468-491. 
Van Praag, C. M., \& Cramer, J. S. (2001). The roots of entrepreneurship and labour demand: Individual ability and low risk aversion. Economica, 68, 45-62.

Wei, W., \& Tang, J. (2019). Ownership transformation, firm performance and manufacturing growth in China. Economics of Transition and Institutional Change, 27, 475-496.

Wilson, R. (2016). Does governance cause growth? Evidence from China. World Development, 79, $138-151$.

Wooldridge, J. M. (2009). On estimating firm-level production functions using proxy variables to control for unobservables. Economics Letters, 104, 112-114.

$\mathrm{Xu}, \mathrm{C}$. (2011). The fundamental institutions of China's reforms and development. Journal of Economic Literature, 49 , 1076-1151.

Yu, M. (2015). Processing trade, tariff reductions and firm productivity: Evidence from Chinese firms. The Economic Journal, 125, 943-988.

Yu, X., Dosi, G., Grazzi, M., \& Lei, J. (2017). Inside the virtuous circle between productivity, profitability, investment and corporate growth: An anatomy of Chinese industrialization. Research Policy, 46, 1020-1038.

Zhang, Q., \& Zou, H.-F. (2012). Regional inequality in contemporary China. Annals of Economics and Finance, 13, $113-137$.

Zhou, W. (2011). Regional deregulation and entrepreneurial growth in China's transition economy. Entrepreneurship \& Regional Development, 23, 853-876.

Zhou, W. (2014). Regional institutional development, political connections, and entrepreneurial performance in China's transition economy. Small Business Economics, 43, 161-181.

Zhou, Y., \& Hall, J. C. (2017). The impact of marketization on entrepreneurship in China: Recent evidence. Working Papers 17-22, Department of Economics, West Virginia University.

Zhu, S., He, C., \& Luo, Q. (2019). Good neighbors, bad neighbors: Local knowledge spillovers, regional institutions and firm performance in China. Small Business Economics, 52, 617-632.

\section{SUPPORTING INFORMATION}

Additional supporting information may be found online in the Supporting Information section.

How to cite this article: Bin P, Chen X, Fracasso A, Tomasi C. Firm employment growth in China: The role of marketization and regional economic factors. Growth and Change. 2020;51:402-439. https://doi.org/10.1111/grow.12348 